\title{
Animal husbandry between the Roman times and the High Middle Ages in central Europe: a biometrical analysis of cattle, sheep and pig
}

\author{
Idoia Grau-Sologestoa ${ }^{1} \cdot$ Francesca Ginella $^{1} \cdot$ Elisabeth Marti-Grädel ${ }^{1} \cdot$ Barbara Stopp $^{1} \cdot$ Sabine Deschler-Erb $^{1}$
}

Received: 17 February 2021 / Accepted: 5 August 2021 / Published online: 30 September 2021

(c) The Author(s) 2021

\begin{abstract}
This paper presents a meta-analysis of biometrical data of cattle (Bos taurus), sheep (Ovis aries), and pig (Sus domesticus), with a diachronic, long-term approach (first-twelfth centuries AD) and at a large regional scale (Switzerland and adjacent areas of France), with the aim of looking at changes in animal husbandry during the transition between Roman times and the Early Middle Ages. With this in mind, a comprehensive biometrical analysis is carried out, on the basis of the log-ratio technique (or logarithmic size index - LSI). The results show an increase of the size of domesticates during the Late Roman period, as well as a long period of size decrease in the subsequent centuries. The possible reasons behind this size decrease are discussed, focusing on three factors: a genetic change, less direct control over feeding and breeding, and changing patterns of herd sex ratios. We argue that these changes should be seen as an efficient adaptation of animal husbandry strategies to broader social, economic, and political transformations.
\end{abstract}

Keywords Zooarchaeology $\cdot$ Livestock management $\cdot$ Size $\cdot$ Economy $\cdot$ Roman Empire $\cdot$ Early medieval $\cdot$ Meta-analysis · LSI

\section{Introduction}

The collapse of the Roman Empire and the long formation processes of medieval societies throughout Europe constitute two major themes in both historical and archaeological research. There is indeed a vast amount of literature discussing these issues (e.g. Wickham 2005 and 2009; Heather 2005; Ward-Perkins 2006; Christie 2009; Bemmann and Quast 2008; Hodges 2012). Archaeologically, research has been carried out notably on settlement patterns, architecture, and material culture, showing a picture of instability, radical changes in settlement patterns, and the termination of most trading routes (e.g. Hodges and Bowden 1998; Marti 2000; Flutsch et al. 2002; Windler et al. 2005; Ward-Perkins 2006; Hodges 2012).

Current theoretical models dealing with medieval economies have emphasised the role that the rural world had on the development of historical dynamics between the Late Roman times and the Early Middle Ages (e.g. Barceló and

Idoia Grau-Sologestoa

idoia.grau@unibas.ch

1 Integrative Prähistorische und Naturwissenschaftliche Archäologie, Universität Basel, Basel, Switzerland
Sigaut 2004; Wickham 2005; Henning 2009; Moreland 2011; Hodges 2012), and in fact, for instance, several recent works have highlighted the huge potential of investigating agricultural change during this key historical period in light of archaeological perspectives (such as various papers in the special journal issues Quirós Castillo 2014; Pigière et al. 2019 and, for the later part of this period, Hamerow et al. 2019 and 2020).

Amongst the different archaeological disciplines, in recent years, zooarchaeology has been a growing field of research for tackling these topics. Zooarchaeological research in different European regions has highlighted the existence of some general patterns in animal husbandry practices during this transitional period, suggesting that changes in the orientation and scale of husbandry practices reflected different socio-political conditions and economic strategies. Roman husbandry practices are known to have impacted considerably on the way domestic animals were raised in the various provinces of the Empire, in particular in relation to a high degree of specialisation of economic activities and increased livestock trade (e.g. Méniel 1996; Breuer et al. 1999; Kron 2002; Minniti et al. 2014; Groot and DeschlerErb 2015 and 2016; Deschler-Erb 2017; Trentacoste et al. 2021). The decline of the Roman political and economic 
structures led to less specialised and more diversified, more local, smaller-scale, self-sufficient subsistence economies in the Middle Ages (e.g. Wickham 2005; Henning 2009; Lewit 2009; Crabtree 2010; Hodges 2012; Akeret et al. 2019). We now understand that the collapse of the Roman Empire and the development of feudal socio-economic structures had important consequences in animal husbandry practices, mainly in relation to the end of market-oriented production, and they might have included a general turn into an economy of self-subsistence, limited livestock mobility (in terms of regional trade, perhaps not so in terms of transhumance), little or no genetic improvement of livestock, and changes in management practices (e.g. feeding regimes).

One of the most promising zooarchaeological approaches to investigating changes in animal husbandry between the later centuries of the Roman period and the Early Middle Ages, across Europe, is biometrical analysis, linking animal size and shape to economic changes. Romans showed a great amount of interest in improving cattle husbandry, as a consequence of the central role of these animals in their economy, both as draught animals, as meat suppliers for a growing non-productive population, as producers of manure, and as providers of the main raw materials for very developed industries such as bone and horn working, as well as leather production. As a result of this interest, cattle size increased considerably. This has been observed in most areas of the Roman Empire: northern Italy (Trentacoste et al. 2021), northern Switzerland (Breuer et al. 1999), Great Britain (Murphy et al. 2000; Grant 2004; Albarella et al. 2007a), the Netherlands (Lauwerier 1988), Belgium (Pigière 2017), Germany (Teichert 1984; Peters 1998; Groot 2017), France (Lepetz 1995 and 1996; Forest and Rodet-Belarbi 2002), and Spain (Mariezkurrena 2004; Colominas and Saña 2010; Fernández and Fuertes 2007; Grau-Sologestoa 2015a; Valenzuela et al. 2017), although some exceptions have been pointed out as well (Davis 2008; Valenzuela-Lamas and Detry 2017; Trixl et al. 2017), proving that it was not an ubiquitous phenomenon, although it was quite generalised. Romans' interest in improved cattle husbandry is also attested by historical sources such as Caesar and Tacitus (Albarella 2007b). In these works, improved animal feeding during Roman times has been suggested as one of the possible reasons behind livestock size increase. Another suggestion is that cattle size increase in Roman times might have been a consequence of the trade of large cattle from the Italian Peninsula (von den Driesch 1992) and/or the Near East or northern Africa (Schlumbaum et al. 2006), to the rest of the Empire. A size increase of sheep has been observed in different European regions in Roman times, including Italy (Mackinnon 2004; Trentacoste et al. 2021), France (Lepetz 1996), England (Albarella et al. 2007a), Spain (Colominas and Saña 2010), and Switzerland (Breuer et al. 2001), although it was less marked than the size increase of cattle. Finally, less is known for pig: there is some evidence for size increase during Roman times in Italy (for example, Trentacoste et al. 2021), but some works have suggested that a reduction of their size might have occurred in Spain (Colominas and Saña 2010).

On the other hand, several works have highlighted what seems to be a very generalised pattern of livestock size decrease after Roman times throughout the former Empire (although with slight variations in terms of timings and animal taxa) that often only increased again during the late- and post-medieval periods (see, for example, Yvinec 1991; Stephan 2008; Rehazek 2010; O'Connor 2010; Hammon 2011; Marti-Grädel 2013; Holmes 2014; Grau-Sologestoa 2015a; Salvadori 2015; and Rizzetto et al. 2017; although differing trends have also been observed - in Portugal, Davis 2008, and in Ireland, McCormick et al. 2014). These works that have played an important role in identifying the scale of this phenomenon, have barely scratched the surface of what is clearly a key topic of interest for (zoo)archaeological approaches into early medieval economies. The reasons behind this livestock size decrease in late antique and early medieval Europe have not been sufficiently discussed, as opposed to the reasons behind livestock size increase in Roman times.

Most of modern-day Switzerland belonged to the Roman Empire during the first five centuries AD. Here, the transition between the Roman times and the Middle Ages was a period of very notable transformations in all aspects (Flutsch et al. 2002; Windler et al. 2005; Niffeler 2014), although the scarcity of historical sources during and after the fifth c. AD is notable. Archaeological research has highlighted a very complicated picture of settlement dynamics, with the decline of urban centres and the reduction in the number of villae rusticae (Schwarz 2011; Berger 2012), as well as local movements of people and the arrival of Germanic populations (Marti 2000, 2008 and 2009) when Franks and Alamannii crossed the river Rhine. This river became the frontier of the Roman Empire in this region from the late third c. AD onwards (Flutsch et al. 2002), and then, the region shifted between different and changing political entities (Windler and Fuchs 2002; Steiner 2014).

A recent overview (Akeret et al. 2019) of the available archaeobotanical and zooarchaeological evidence recovered in Switzerland, dated to this transitional period, has demonstrated the change from a surplus production to a subsistence economy, a diversification of the production, the reduction of cultivated areas, and the contraction of long-distance trade. At the same time, some influences from the northern regions are documented, with an increase in the production of antler goods, the possible consumption of horse meat, and the cultivation of rye (Secale cereale), while some Roman innovations persisted (such as the cultivation of vines and fruit trees, as well as poultry breeding). The later parts of the 
Early Middle Ages saw the birth of manorialism/feudalism, open field systems, the re-introduction of heavy ploughs, and the move from a two-field system to a three-field system of agriculture (Niffeler 2014; Frosdick 2014).

For central Europe, and specifically for the geographic area in proximity to the Roman Germanic limes, some works (Teichert 1984; Breuer et al. 1999 and 2001; MartiGrädel 2012 and 2013; Frosdick 2014; and Putelat 2015) have suggested patterns of livestock size change similar to those present in other European areas, with an increase in Roman times and a decrease in the early medieval period. However, these relevant works have only scratched the surface of what is clearly a complicated process, and the exact timing and geographical patterns of these changes are not entirely clear. This paper contributes to this debate by further exploring the processes of change in animal husbandry between the Roman times (first-fifth c. AD) and the Middle Ages (sixth-twelfth c. AD) in central Europe (specifically, Switzerland and central-eastern France), based on a metaanalysis of biometrical data of cattle, sheep, and pig recovered in a number of archaeological sites, including newly acquired data. Specific aims of this paper are:

- To confirm (or not) previously suggested patterns of livestock size change in the study region, with the largest dataset collected to date,

- To determine the timings of these changes, using a periodisation as precise (in terms of time resolution) as possible, and

- To discuss at length the possible reasons behind livestock size decrease as a result of human action, either deliberate or not.

\section{Materials and methods}

\section{The sites and periods}

The main evidence used in this paper is biometrical data (Grau et al. 2021) ${ }^{1}$ of cattle, sheep, and pig remains, spanning from Roman times to the High Middle Ages, with a special attention to changes between the Late Roman times and the subsequent early medieval centuries, from a number of archaeological sites located in Switzerland and centraleastern France.

This work is a meta-analysis of biometrical data gathered directly by the authors of this paper, and completed by measurements taken by other colleagues and available in published literature. The list of period-sites used $(85$ period-sites from 61 sites) with references to their original publications are provided in the Supplementary Materials

$\overline{1}$ The dataset is available at http://doi.org/10.5281/zenodo.4707131
(SM1). The location of the sites is shown in Fig. 1. These sites cover mainly the north and the southwest of Switzerland, the French region of Alsace, and the "arc Jurassien", with sites from both sides of the French-Swiss border. Environmental differences between sites are to be expected in such a regional review; for instance, some sites are located in the Swiss Central Plateau - the hilly area between the Alps and the Jura mountains (e.g. Augusta Raurica, Basel, etc.) - some along the course of the Rhine river (e.g. Strasbourg), while others are in more mountainous areas (e.g. Sion). However, the majority of the sites are located in areas with relatively similar environmental conditions and are similarly represented in the different time-periods; therefore, it is unlikely that the biometrical analysis is affected by changes in site distribution. On the other hand, at the present state-of-the-art, it is unclear how differences in the distribution of site-types across the different periods might explain the biometrical changes, and the sample size is still too limited to attempt such an analysis. However, this factor will be considered in our discussion, in light of settlement changes through time.

The largest amount of data comes, however, from Augusta Raurica (or Colonia Augusta Rauracorum), one of the most well-known archaeological sites and open-air museums in Switzerland, spanning from the late first century BC to the mid third century AD, when an earthquake first and the arrival of the Alemanni later destroyed large parts of the city (Schwarz 2011). The Roman military forces built then a fortress, Castrum Rauracense, just north of the city and closer to the Rhine river, with an associated civilian settlement located in its vicinity (suburbium), that lasted at least until the early seventh century. Until then, it remained the bishopric seat of the region; in the seventh or eighth century, the seat was moved to Basel.

For the purpose of this analysis, the dataset has been divided in various chronological phases, with the aim of approaching the analysis with a time resolution as precise as possible:

- Roman Empire (first-mid third c. AD),

- Late Roman (mid third-fifth c. AD),

- early Early Middle Ages (sixth-seventh c. AD),

- late Early Middle Ages (eighth-tenth c. AD), and

- High Middle Ages (eleventh-twelfth c. AD).

An "Early Middle Ages" phase was used when chronological information did not allow separating between 'early' and 'late'. When the sample size was too small to treat both periods separately, the period-sites dated as "early Early Middle Ages" and "late Early Middle Ages" were added into a more generic "Early Middle Ages" phase, comprising the sixth-tenth c. Period-sites that fell into the transition between two of the above chronological phases, were 


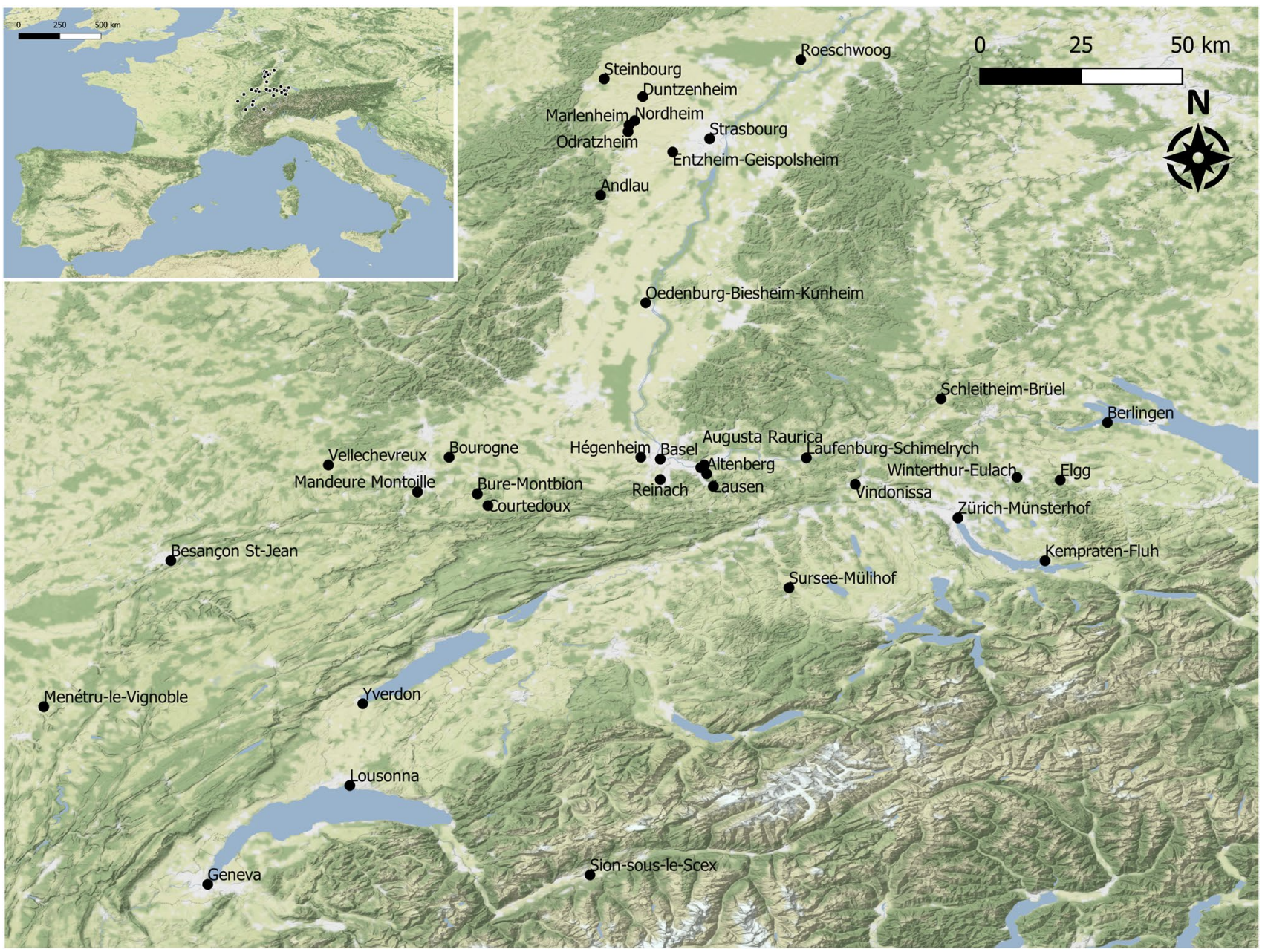

Fig. 1 Map showing the location of the sites discussed in this paper

assigned to the one that was longer (for example, data from Augusta Raurica-Frauenthermen, dated to 180-270, has been assigned to the Roman Empire phase rather than the Late Roman one).

\section{The biometrical analysis}

Cattle, followed by pig, were the most common animal taxa in the geographic area and time periods studied in this paper (Frosdick 2014; Deschler-Erb 2017; Akeret et al. 2019). Attention has been put on sheep rather than goat (Capra hircus) as this species was generally more common. As it is well known, distinguishing sheep and goat remains based on morphological criteria is quite complicated and often zooarchaeologists use the more general taxon "sheep/ goat" to refer to those elements that cannot be distinguished with certainty. For the present analysis, ideally, only sheep measurements should have been used, but they are not very frequent, and their identification largely relies on the individual judgement of each specialist. The exclusion of the sheep/goat measurements from the analysis would have meant a great reduction of the sample size. Therefore, sheep/goat measurements have also been used, and plotted separately from sheep whenever possible. Elements clearly determined as goat have been excluded. Available evidence from Augusta Raurica suggests that the frequency of goats increased slightly during the Roman period (e.g. Schibler and Furger 1988:20), probably in relation to their increasing role in horn-working, and decreased again during the Early Middle Ages, although they were generally fewer than the sheep. In the Supplementary Material (SM2), we have attempted to look at sheep and goat ratios between the Late Roman and high medieval periods in north-western Switzerland, where the data is more abundant. Sheep are generally more frequent than goats throughout the period in a ratio of approximately 3 to 1 . The possible presence of some goat bones within the measurements labelled "sheep/goat" may have had an impact on observed patterns, but that impact is likely comparable for all periods except for the seventh century, when the proportion of goat increased to being more 
Table 1 List of measurements used in the analysis

\begin{tabular}{|c|c|}
\hline \multicolumn{2}{|l|}{ Cattle } \\
\hline Postcranial widths & $\begin{array}{l}\text { Astragalus Bd, humerus BT (and when not available, Bd preferred over SD), metacarpus Bd (and when not available, } \\
\text { Bp preferred over SD), metatarsus Bd (and when not available, Bp preferred over SD), tibia Bd, scapula SLC, radius } \\
\text { Bd (and when not available, Bp preferred over SD), pelvis LA, femur DC (and when not available, Bd preferred over } \\
\text { SD) }\end{array}$ \\
\hline Postcranial lengths & $\begin{array}{l}\text { Astragalus GLl (and when not available, GLm), calcaneus GL, humerus GL, metacarpus GL, radius GL, femur GL, } \\
\text { tibia GL, and metatarsus GL }\end{array}$ \\
\hline \multicolumn{2}{|l|}{ Sheep } \\
\hline Postcranial widths & $\begin{array}{l}\text { Scapula SLC (and when not available, GLP), humerus BT (and when not available, SD), radius Bp (and when not } \\
\text { available, BFp is preferred over SD), metacarpus Bd - BFd in standard - (and when not available, Bp - BFp in } \\
\text { standard - is preferred over SD), femur SD, tibia Bd (and when not available, SD), astragalus Bd, metatarsus Bd - } \\
\text { BFd in standard - (and when not available, SD) }\end{array}$ \\
\hline Postcranial lengths & $\begin{array}{l}\text { humerus HT (and when not available, HTC), radius GL, metacarpus GL, tibia GL, calcaneus GL, astragalus GLl (GL in } \\
\text { standard), metatarsus GL }\end{array}$ \\
\hline \multicolumn{2}{|l|}{ Pig } \\
\hline Postcranial widths & $\begin{array}{l}\text { Humerus BT (and when not available, Bd), radius Bp (and when not available, SD), ulna SDO, pelvis LAR, femur DC, } \\
\text { tibia Bd, metacarpus III and IV Bp, and metatarsus III and IV Bp }\end{array}$ \\
\hline Postcranial lengths & Astragalus GLl (and when not available, GLm), and calcaneum GL \\
\hline Tooth lengths & $\begin{array}{l}\text { Only one measurement per jaw is considered, prioritising M1L when present. If not available, another measurement } \\
\text { from the same jaw was used (prioritising: M1L }>M 2 L>M 3 L \text { ) }\end{array}$ \\
\hline Tooth widths & $\begin{array}{l}\text { Only one measurement per jaw is considered, prioritising M1WP (for lower teeth) or M1WA (for upper } \\
\text { teeth) when present. If not available, another measurement from the same jaw was used (prioritising: } \\
\text { M1WP }>\text { M2WP }>\text { M3WA }>\text { P4W for lower teeth, and M1WA }>\text { M2WA }>\text { M3WA }>\text { P4W for upper teeth) }\end{array}$ \\
\hline
\end{tabular}

than half of the caprine bones identified to species level. The difference between sheep and goat is of shape rather than size, with goat postcranial bones being in general slenderer than those of sheep (with the exception of metapodials, for which the pattern is inverted - sheep metapodials are slenderer than goat metapodials). Therefore, it is necessary to look at measurements in different axes to see in what way the inclusion of goat measurements might have affected the biometric patterns, especially for the seventh century.

For analysing pig biometry, data recorded originally as Sus domesticus (pig) or Sus sp. (pig or wild boar) have been merged. Animals that were recorded as Sus scrofa (wild boar) have not been considered. We decided not to try to split the sample between the wild and domestic forms, due to the difficulty of doing so. In the Supplementary Materials (SM3), however, specific biometrical analyses on single measurements (as suggested by Albarella and Payne 2005), anterior width and length of lower third molars - SM3 A - and astragalus GL1 — SM3 B) have been performed to see if wild boars might be present under "Sus sp." and therefore distorting the results. The analyses suggest that wild boars might be present, but probably represented by just a few large outliers.

The core of the present biometrical analysis is based on the log-ratio technique (sometimes referred to in the literature as "LSI technique"), a method first used in zooarchaeology by R. Meadow (1999), which allows direct comparison between different measurements and, therefore, increases sample size (Albarella 2002; Wolfhagen 2020). It is a size index scaling technique that transforms logarithmically ${ }^{2}$ the ratio between measurement data and standard measurements, which are taken from an individual or from the mean of a given population (Payne and Bull 1988), either modern or archaeological. The value resulting from this calculation is the "logarithm size index" (or LSI value).

Only a selection of all possible measurements was considered for the analysis based on the log-ratio technique (Table 1) (a more detailed explanation is provided in the Supplementary Materials — SM4). The measurements that were chosen are especially common in archaeological assemblages because these parts of the skeleton tend to be well preserved and, moreover, these measurements can be easily defined and taken, and therefore, are well suited for comparison across different researchers. Also, these measurements were chosen because of their relatively low sexual dimorphism (and when they are sexually dimorphic - e.g. metapodial $\mathrm{Bd}$ - a separate analysis has been conducted), and because they are not amongst the most age dependent. In this work, the priority was to investigate morphometric differences between livestock types over time, rather than the

\footnotetext{
${ }^{2}$ In this paper, the LSI values have been calculated with logarithm base $10\left(\mathrm{LSI}_{10}\right)$.
} 
identification of age and sex groups. These must be considered in the interpretation of the results, however, and specific analyses have been carried out for this purpose.

The broad biometrical analysis based on large regional patterns in this paper, carried out on the basis of the log-ratio technique, is also complemented by site- and measurementspecific biometric analysis, in order to make sure of the significance of the observed general patterns and allow more in-depth observations. For instance, specific biometrical analysis has been carried out on metapodial Bd and humerus BT of cattle, in order to look at changes related to sex ratios.

There is better correlation between measurements taken along the same axis (Davis 1996), and ideally, only measurements taken in the same plane should be combined in the log-ratio technique. This approach has been followed here: postcranial length and width measurements have been plotted separately. Depth measurements are too few and have been excluded from the analysis. Unfused bones have not been included and extreme outliers were identified by the statistical software ${ }^{3}$ and removed for the analysis, because a close examination led us to assume that they were most likely data entry errors (i.e. too small/large values for a given measurement). Only one measurement per bone has been used in all cases. Teeth measurements have only been used for pigs; cattle and sheep teeth measurements were too few, as they are not often recorded. This is unfortunate, as teeth are known to be more conservative and less plastic than bones, and therefore their size is less affected by sex, age, and environmental factors, making them more direct indicators of genetic change (Payne and Bull 1988; Albarella 2002).

For cattle and pig, the set of standard measurements (for full details see Supplementary Materials - SM5) used comes from two individuals of known sex, age, and origin that are part of the reference collection at the IPNA-Basel ${ }^{4}$ (the cattle standards are also published in Breuer et al. 1999). For sheep, the standards were derived from a group of Shetland sheep (Davis 1996).

Exploratory biometrical analyses have been complemented, when relevant, by statistical tests. The tests of normality (Kolmogorov-Smirnov and Shapiro-Wilk) showed, in all cases, that data were not-normally distributed, and

\footnotetext{
${ }^{3}$ Extreme outliers are $\mathrm{LSI}_{10}$ data values lying outside of the outer fences, which are set at a distance of $2 \times$ step of the first and third quartiles. Step is defined as $\mathrm{m} \times \mathrm{IQR}$ (interquartile range); $\mathrm{m}$ is often 1.5 , sometimes 2 or 2.5 . The interquartile range is defined as $\mathrm{IQR}=\mathrm{H}_{3}-\mathrm{H}_{1}$, where $\mathrm{H}_{3}$ and $\mathrm{H}_{1}$ are the third $\left(\mathrm{Q}^{3}\right)$ and first quartiles $\left(\mathrm{Q}_{1}\right)$. Extreme outlier: $\mathrm{x}_{\mathrm{i}} \geq \mathrm{H}_{3}+2 \times$ step or $\mathrm{x}_{\mathrm{i}} \leq \mathrm{H}_{1}-2 \times$ step (Horber 2020).

4 The standards calculated from materials stored at IPNA are available to use in the following link: https://ipna.duw.unibas.ch/de/forsc hung/archaeobiologie/archaeozoologie/methodik/. More information is provided in the Supplementary Materials - SM5.
}

therefore, non-parametric tests were carried out. In the first instance, a Kruskal-Wallis $H$ test was performed and, afterwards, post hoc pairwise comparisons were carried out with a Mann-Whitney $U$ test, the results of which were adjusted using the Bonferroni correction. $P$-values of these tests and effect sizes ${ }^{5}$ are reported in this paper.

A large biometrical dataset ${ }^{6}$ (Grau et al. 2021) is used for the present paper, with a total number of almost 4000 measurements, of which more than 1500 belong to cattle, almost 1000 belong to sheep, and 1400 belong to pig (the exact numbers per period-site are provided in the Supplementary Materials - SM6). This large body of data has allowed us to undertake a full comparative analysis aimed at identifying the timing and nature of animal husbandry changes during the transition between Roman times and the Early Middle Ages for the study region.

\section{Results}

\section{Cattle}

Supplementary Material SM6 summarises the number of cattle measurements (widths and lengths) used for the present biometrical analysis. The sample size is more substantial for width measurements than for length measurements. In both types of measurements, the number available is smaller for the late Early Middle Ages, and therefore, the statistical analyses (summarised in Table 2) have been performed also by combining the early and the late Early Middle Ages.

Figures 2 and 3 show box plots of the $\mathrm{LSI}_{10}$ values of cattle postcranial measurements (widths and lengths, respectively). Measurements from both axes show very similar patterns through time: cattle increased in size during the Late Roman times and decreased immediately afterwards, getting progressively smaller during the early and high medieval periods, reaching their minimum average size during the High Middle Ages.

Table 2 provides the summary of the observed trends and the statistical results of the pairwise comparisons (Mann-Whitney $U$-tests). These tests show that the observed size differences between the different periods are statistically very or highly significant $(P$-value $\leq 0.01)$ in almost all cases. The only exception (the Late EMA-HMA pair for length measurements) is probably due to the small sample

\footnotetext{
${ }^{5}$ Effect sizes are reported with the estimate $r$ (Rosenthal 1991:19), as follows $r=\frac{Z}{\sqrt{N}}$, and thresholds are considered according to the levels introduced by Cohen (1988).

6 The whole dataset is available here: http://doi.org/10.5281/zenodo. 4707131.
} 
Table 2 Summary of the observed trends and statistical results of pairwise comparisons for cattle biometrical data. $P$ values are reported (an alpha value of 0.05 is used to assess statistical significance). $* * *$, very significant (alpha value $\leq 0.001$ ); **, highly sig- nificant (alpha value $\leq 0.01$ ); * significant (alpha value $\leq 0.05$ ). Effect size: small effect if smaller than 0.1 , small to medium if between 0.1 and 0.3 , medium to high if 0.3 to 0.5 , and very high if above 0.5

\begin{tabular}{|c|c|c|c|c|c|c|}
\hline & \multicolumn{3}{|l|}{ Widths } & \multicolumn{3}{|l|}{ Lengths } \\
\hline & Observed & Sig & Effect size & Observed & Sig & Effect size \\
\hline Roman Empire-Late Roman & Increase & $0.000 * * *$ & 0.16 & Increase & $0.006^{* *}$ & 0.23 \\
\hline Late Roman-early EMA & Decrease & $0.000 * * *$ & 0.39 & Decrease & $0.000 * * *$ & 0.40 \\
\hline Early EMA-late EMA & Decrease & $0.001 * * *$ & 0.16 & Decrease & $0.004 * *$ & 0.31 \\
\hline Late EMA-HMA & Decrease & $0.000 * * *$ & 0.23 & Similar on average & 0.059 & - \\
\hline Late Roman-EMA (all periods) & - & - & - & Decrease & $0.000 * * *$ & 0.51 \\
\hline EMA (all periods)-HMA & - & - & - & Decrease & $0.000 * * *$ & 0.32 \\
\hline
\end{tabular}

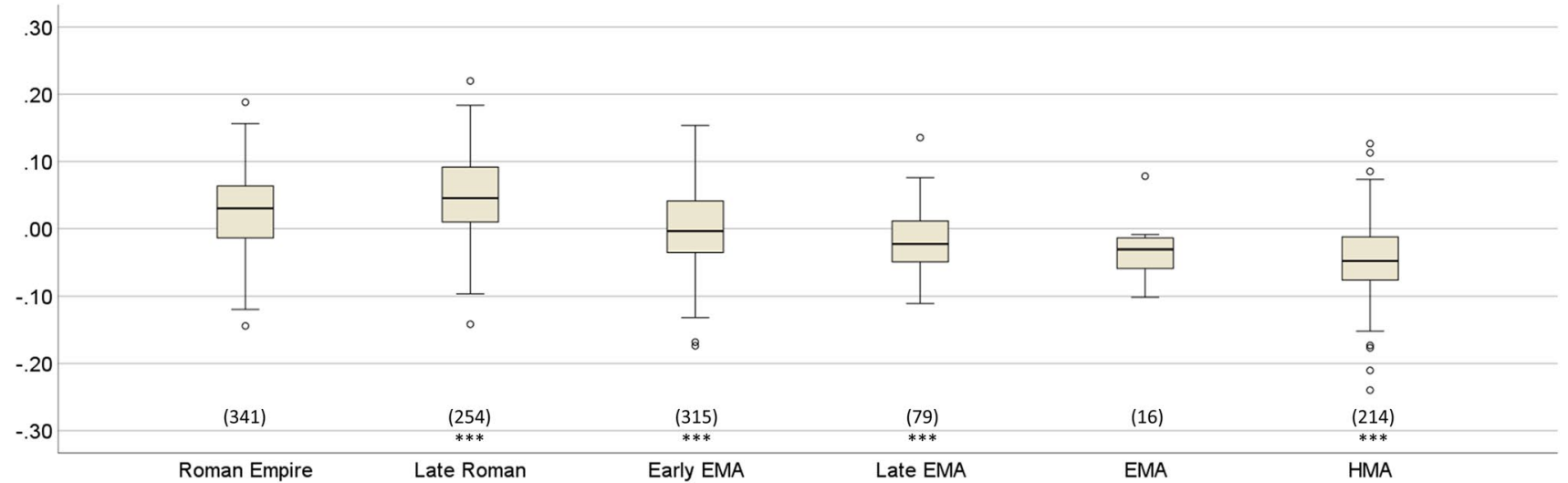

Fig. 2 Box plots showing the $\mathrm{LSI}_{10}$ values of cattle postcranial widths, divided by period. In brackets, number of measurements. $P$ values are reported (an alpha value of 0.05 is used to assess statistical significance): $* * *$, very significant (alpha value $\leq 0.001)$; **, highly significant (alpha value $\leq 0.01$ ); $*$ significant (alpha value $\leq 0.05$ )

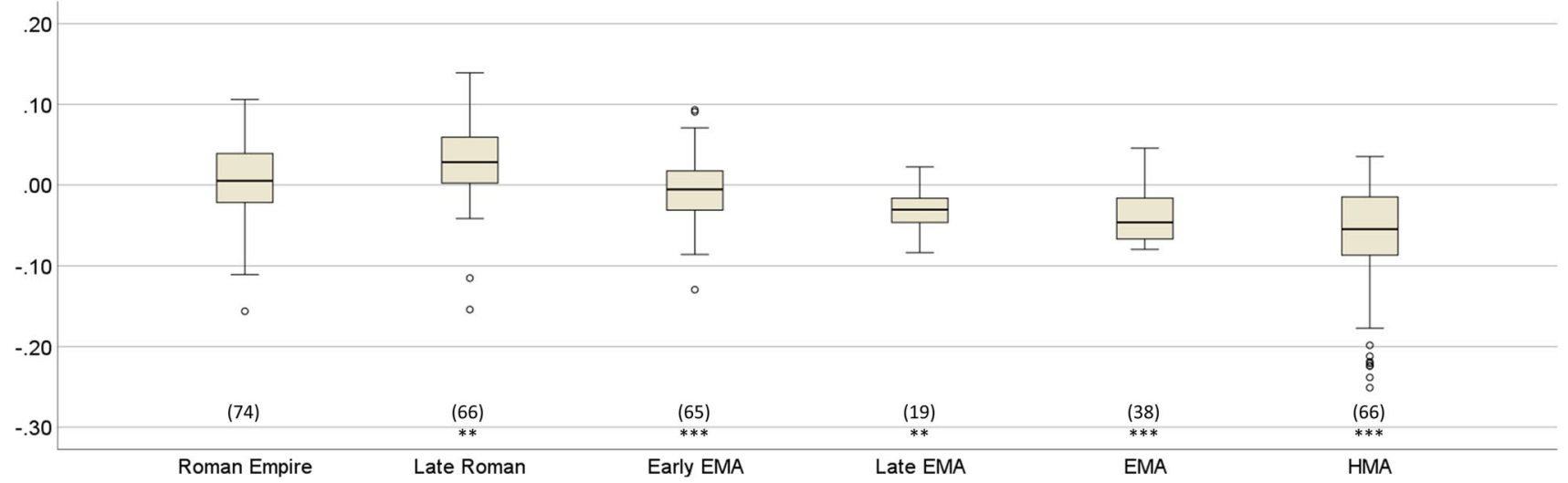

Fig. 3 Box plots showing the $\mathrm{LSI}_{10}$ values of cattle postcranial lengths, divided by period. In brackets, number of measurements. $P$ values are reported (an alpha value of 0.05 is used to assess statistical significance): ***, very significant (alpha value $\leq 0.001$ ); **, highly significant (alpha value $\leq 0.01$ ); * significant (alpha value $\leq 0.05$ )

Size variability, according to both width and length measurements, seems to remain quite stable throughout most of medium to high in most cases. 


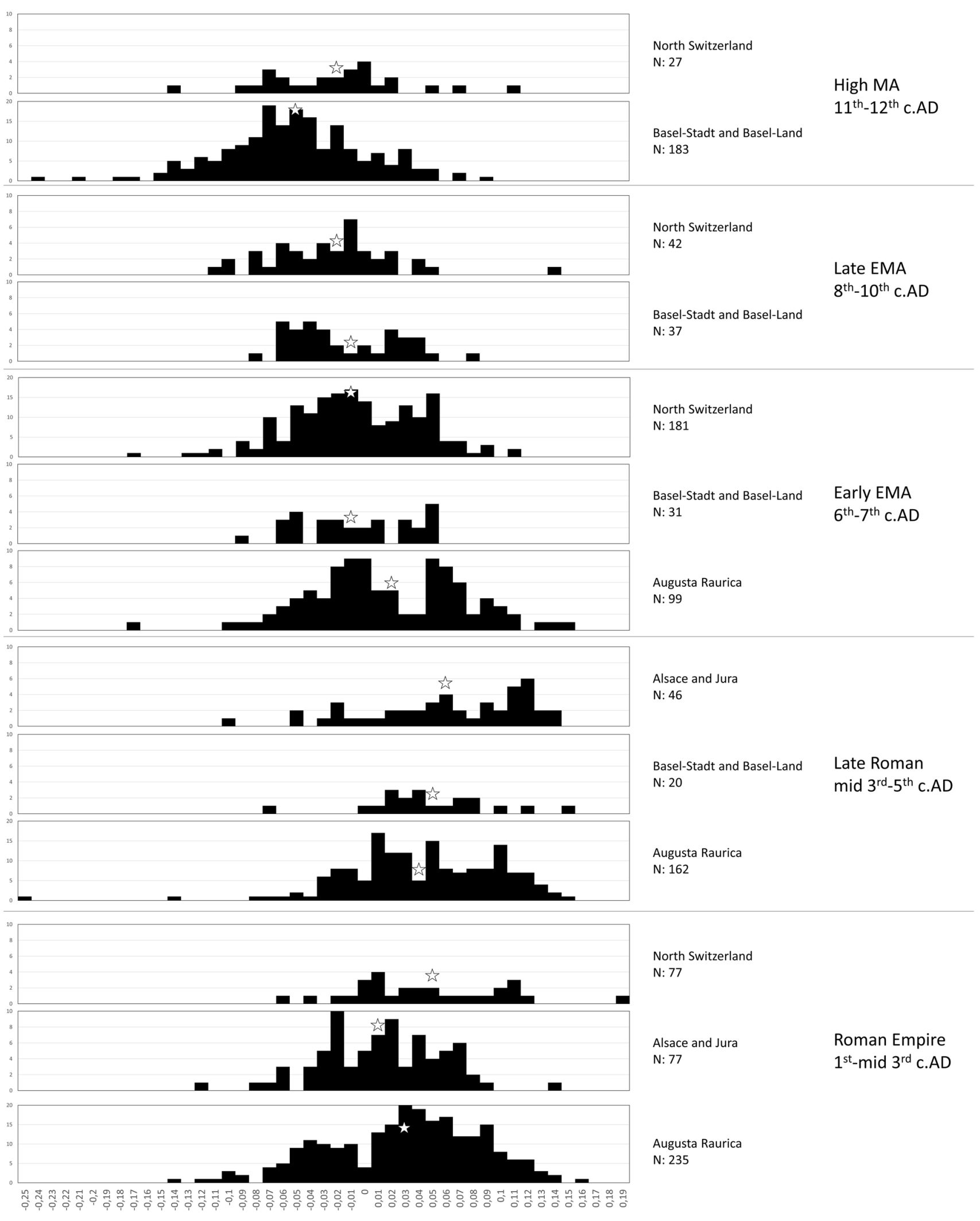

Fig. 4 Histograms with $\mathrm{LSI}_{10}$ values of cattle postcranial width measurements, by period. Different sites have been grouped in larger regions (except Augusta Raurica, which is shown by its own), and only those with N > 20 are shown. The star symbols show the average of each group 
Fig. 5 Histograms with $\mathrm{LSI}_{10}$ values of cattle sexually dimorphic measurements, by period. Black: metacarpal BD; dark grey: metatarsal BD; light grey: humerus BT

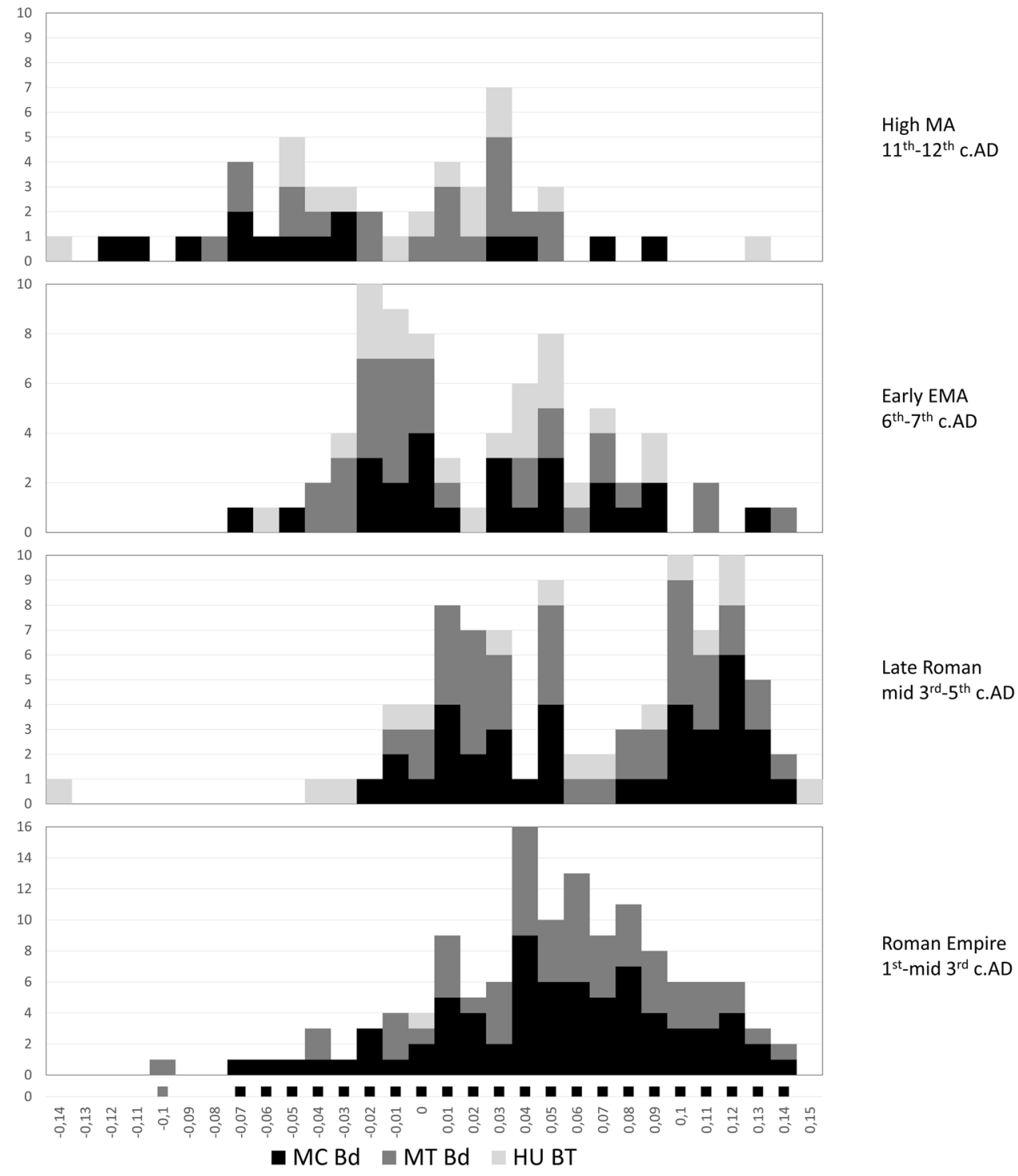

the periods considered here. A slight reduction of size range is visible in the later early medieval period, but this is quite likely due to the overall smaller sample size of this phase compared to the other ones. Cattle size range seems to be wider for the High Middle Ages, both in width and length measurements.

In order to explore more specific differences through time, cattle biometric $\mathrm{LSI}_{10}$ data (only widths, as the sample size is larger than for lengths) have been plotted in the histograms shown in Fig. 4, according to different geographic regions. The overall patterns are those highlighted above: an increase in cattle size in the Late Roman period, followed by a gradual decrease during medieval times. Despite none of the regions provided enough data throughout the five chronological periods, which would have been ideal, this more specific approach highlights some interesting differences between regions. The Late Roman increase in size seems to be more acute in Alsace and Jura, while the increase is less marked in Augusta Raurica. During the early Early Middle Ages, cattle from Augusta Raurica were the largest in the studied area, while cattle from Basel-Stadt and Basel-Land and other northern Swiss areas were smaller (and similar in size with one another). Afterwards, cattle size decreased again, more clearly in Basel than in North Switzerland, but both reaching their minimum average size during the High Middle Ages. Subtler differences appear between individual sites: for example, a few large cattle individuals were identified in 11th c. Altenberg (a site in Basel-Land), interpreted as oxen (Marti-Grädel 2012 and 2013).

In Fig. 5, some of the highly sexually dimorphic cattle measurements (metacarpal and metatarsal $\mathrm{Bd}$, and humerus BT) have been plotted chronologically (although there are too few measurements for the late Early Middle Ages). The graphs for the Late Roman times, early Early Middle 
Fig. 6 Histograms with $\mathrm{LSI}_{10}$ values of cattle sexually dimorphic measurements (metacarpal and metatarsal $\mathrm{Bd}$ and humerus BT), Roman Empire period

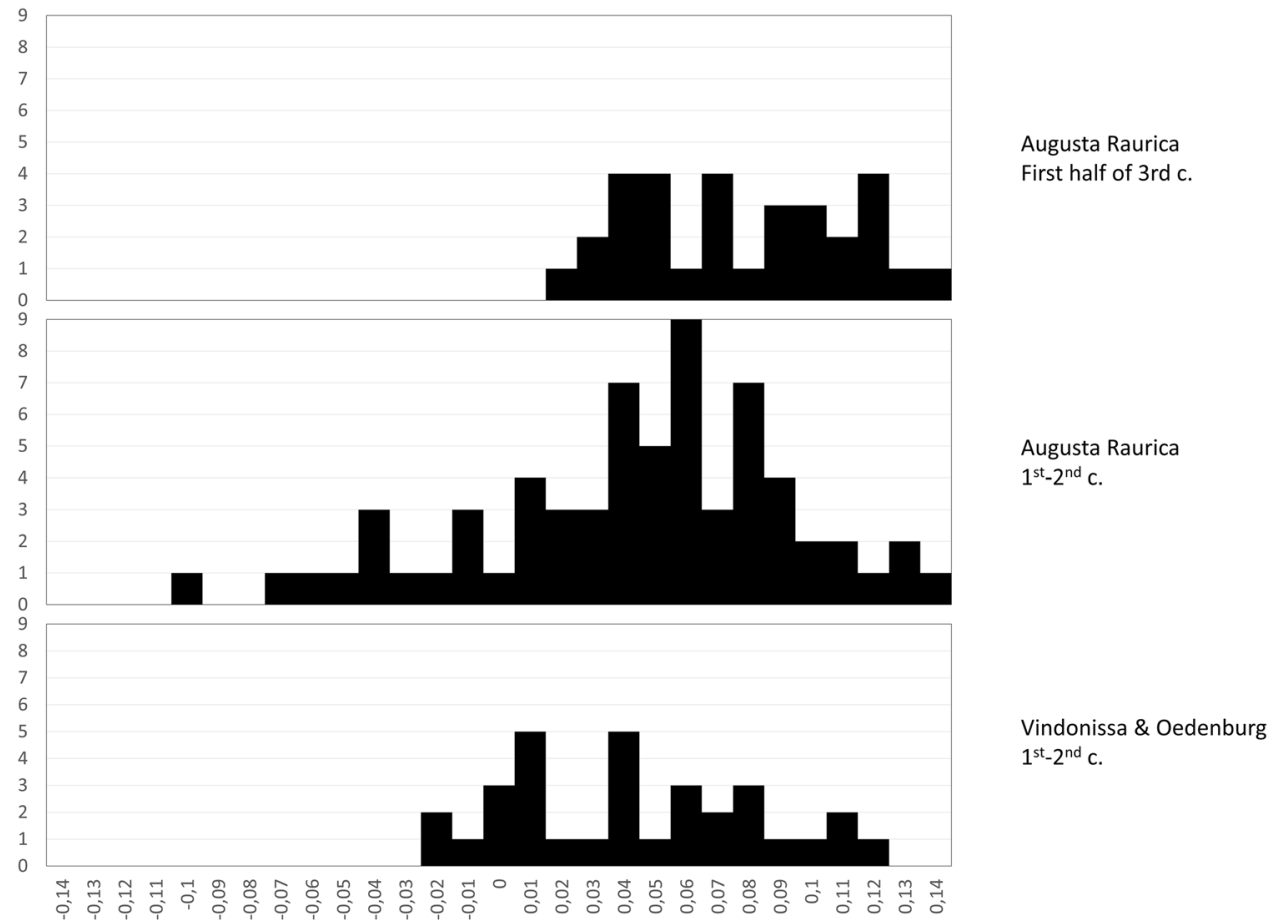

Ages, and High Middle Ages show a bimodal distribution, indicative of female and male groups (the latter, possibly predominated by castrated individuals, as it would not make sense to keep such a large proportion of bulls). Interestingly, both sex groups do not change in a substantial proportion, suggesting that sex ratios did not vary significantly through early medieval times and, moreover, the data plotted in these graphs show that both groups decreased in size throughout the medieval periods. In other words, the progressive size decrease observed for cattle after the Late Roman times is not related to changes in sex ratios but, rather, a true size decrease of cattle populations. There is, however, a change between the Roman times and the Late Roman times that may suggest a small increase in the proportions of female cattle, and possibly, smaller presence of castrates.

When we break down the cattle sexing data of the Roman period into smaller groups, the smaller sample size prevents us from reaching clear conclusions, but the data is nonetheless suggestive (Fig. 6): in Augusta Raurica during the first-second c., male (predominantly castrated) cattle were being brought into the city, but with a small number of females present, as the data would seem to be skewed towards the right of the graph. The contemporary cattle found in Vindonissa and Oedenburg, on the other hand, show a much reduced variability in cattle size, and the data is probably too few to reconstruct sex patterns with certainty. This difference in cattle size between Augusta Raurica and the other contemporary sites is probably due to the fact that this urban settlement was the most important in the area. It is noteworthy, though, that smaller cattle (possibly females) are not found in the later period of Roman Augusta Raurica (first half of third c.).

\section{Sheep}

There are relatively fewer biometrical data available for sheep, compared to cattle and pig (Supplementary materials SM6). Definite sheep measurements account for approximately half of the measurements considered for each grouping.

Figures 7 and 8 show box plots of the $\mathrm{LSI}_{10}$ values of sheep and sheep/goat postcranial measurements (widths and lengths, respectively). Width measurements (Fig. 7) show patterns very similar to those described for cattle: an increase in size for the Late Roman period, followed by a progressive decrease in the Middle Ages, arriving to a minimum average value during the High Middle Ages. Size variability remained quite stable across the five periods considered here, with a reduction of the range for the late Early Middle Ages, according to width values.

Length measurements, on the other hand, show different patterns (Fig. 8). Late Roman values remained similar to those of the earlier period, suggesting that Late Roman sheep became wider but not taller (that is, they became stockier, rather than overall larger). Sheep size decreased in the early Early Middle Ages, remained similar during the late early medieval period (although with a decrease of the average value), and experimented a very slight increase in size during the High Middle Ages, meaning that high 


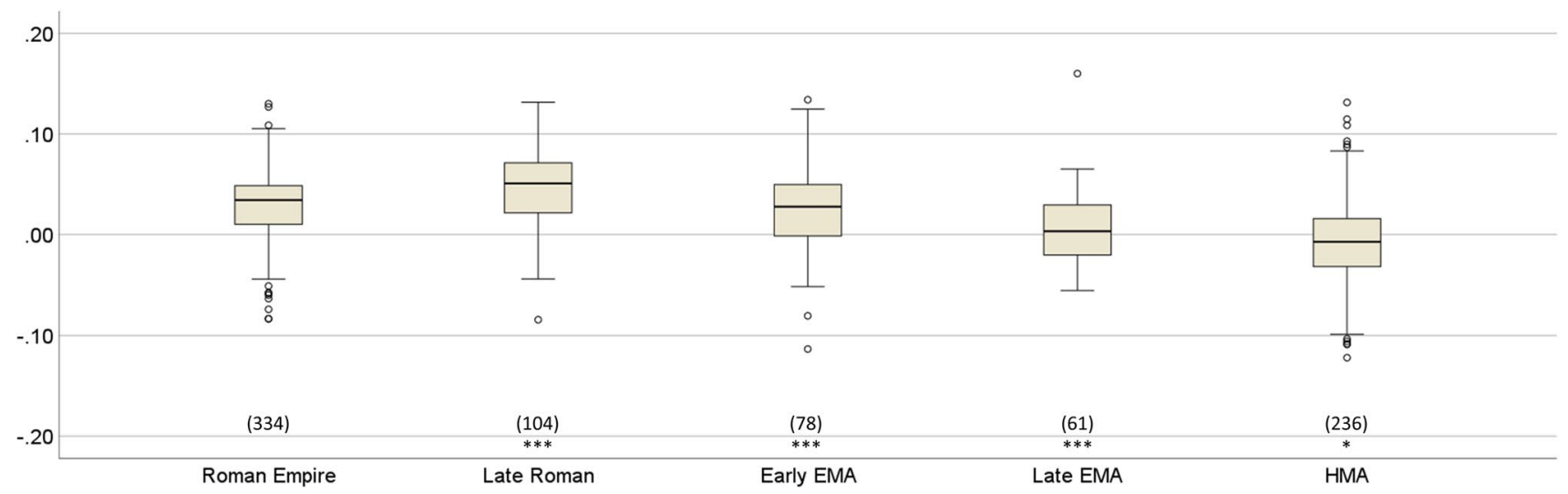

Fig. 7 Box plots showing the $\mathrm{LSI}_{10}$ values of sheep postcranial widths, divided by period. In brackets, number of measurements. $P$ values are reported (an alpha value of 0.05 is used to assess statistical

significance): $* * *$, very significant (alpha value $\leq 0.001)$; $* *$, highly significant (alpha value $\leq 0.01) ; *$ significant (alpha value $\leq 0.05$ )



Fig. 8 Box plots showing the $\mathrm{LSI}_{10}$ values of sheep postcranial lengths, divided by period. In brackets, number of measurements. $P$ values are reported (an alpha value of 0.05 is used to assess statistical significance): ***, very significant (alpha value $\leq 0.001$ ); **, highly significant (alpha value $\leq 0.01$ ); * significant (alpha value $\leq 0.05$ )

significant (alpha value $\leq 0.05$ ). Effect size: small effect if smaller than 0.1 , small to medium if between 0.1 and 0.3 , medium to high if 0.3 to 0.5 , and very high if above 0.5 pairwise comparisons for sheep biometrical data. An alpha value of 0.05 is used to assess statistical significance. $* * *$, very significant (alpha value $\leq 0.001$ ); **, highly significant (alpha value $\leq 0.01$ ); *

\begin{tabular}{|c|c|c|c|c|c|c|}
\hline & \multicolumn{3}{|l|}{ Widths } & \multicolumn{3}{|l|}{ Lengths } \\
\hline & Observed & Sig & Effect size & Observed & Sig & Effect size \\
\hline Roman Empire-Late Roman & Increase & $0.000 * * *$ & 0.20 & Similar & 0.984 & - \\
\hline Late Roman-early EMA & Decrease & $0.000 * * *$ & 0.26 & Decrease & $0.017 *$ & 0.39 \\
\hline Early EMA-late EMA & Decrease & $0.006^{* *}$ & 0.24 & Similar & 0.403 & - \\
\hline Late EMA-HMA & Decrease & $0.023^{*}$ & 0.13 & Increase & $0.037^{*}$ & 0.30 \\
\hline Late Roman-EMA (all periods) & - & - & - & Decrease & $0.001 * * *$ & 0.44 \\
\hline EMA (all periods)-HMA & - & - & - & Increase & 0.055 & - \\
\hline
\end{tabular}




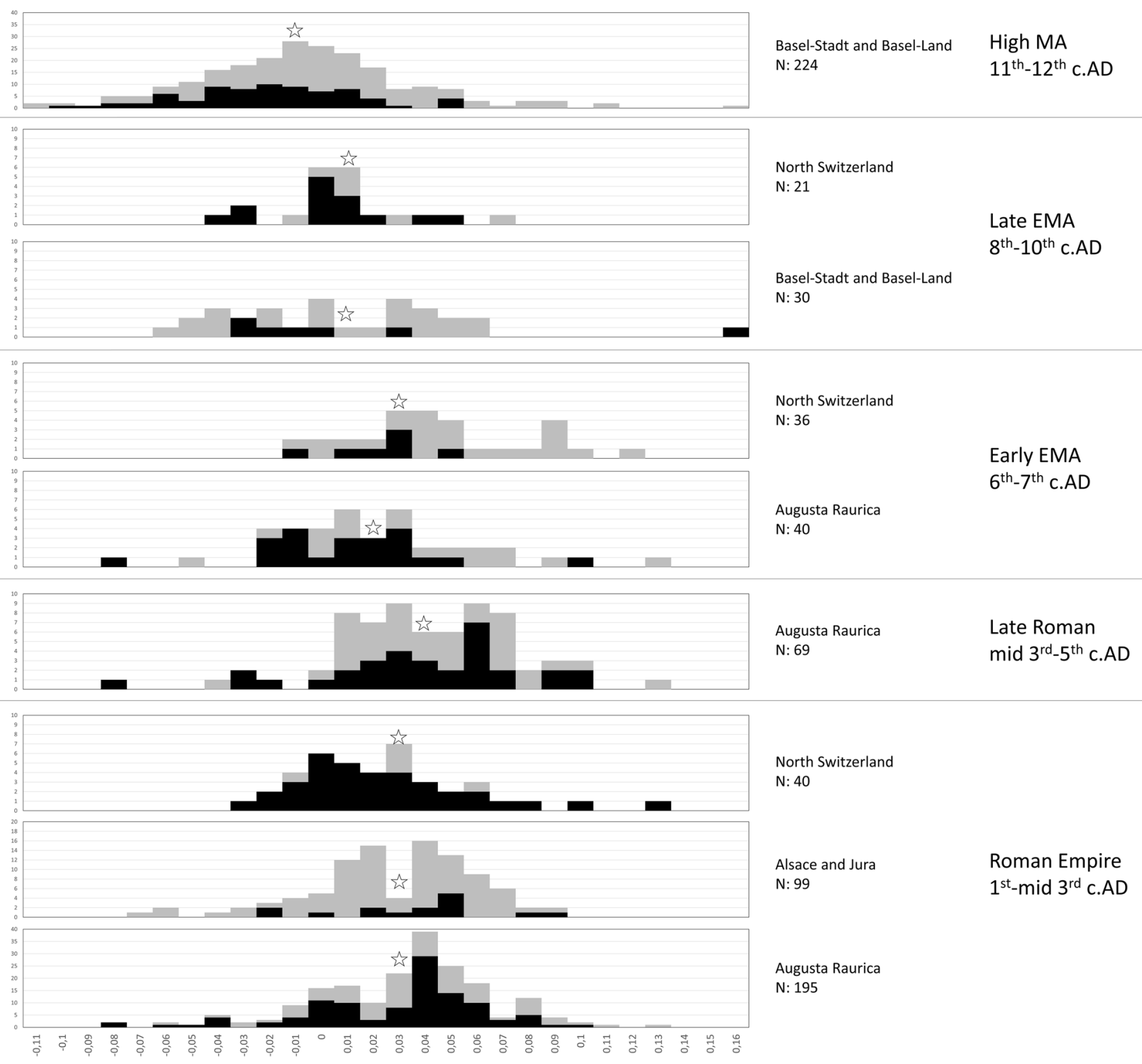

Fig. 9 Histograms with $\mathrm{LSI}_{10}$ values of sheep (sheep in black and sheep/goat in grey) postcranial width measurements, by period. Different sites have been grouped in larger regions (except Augusta

medieval sheep were rather slender, compared to the previous period.

Table 3 summarises the observed trends and offers the statistical results of the Mann-Whitney $U$-tests for the pairwise comparisons. The results show very significant differences between all the different groups of width measurements (with $P$-values being especially significant for the Roman Empire-Late Roman and Late Roman-early EMA pairs). For length measurements, the statistical tests showed significant differences for the aforementioned periods of size decrease and increase (although the $P$-values are not as low as for width measurements, probably due to
Raurica, which is shown by its own), and only those with $\mathrm{N}>20$ are shown. The star symbols show the average of each group

the smaller sample size), and no difference for those periods in which size remained without any visible changes (that is, between the pairs Roman Empire-Late Roman and the early EMA-late EMA). Effect sizes are small to medium for all width pairs, and medium to high in all length pairs.

We need to consider how the inclusion of goat measurements within the "sheep/goat" category might have affected these patterns. As we discussed earlier, we believe that the impact is likely to be comparable for all periods, except for the seventh century, as the evidence suggest that the ratio of goats increased then. Furthermore, the data in these graphs 
Fig. 10 Sheep sexing data, Augusta Raurica, Roman Empire: histogram with $\mathrm{LSI}_{10}$ values of sheep (in black) and sheep/goat (in grey) postcranial width measurements, only considering metacarpal and metatarsal Bd and humerus BT. $N=54$



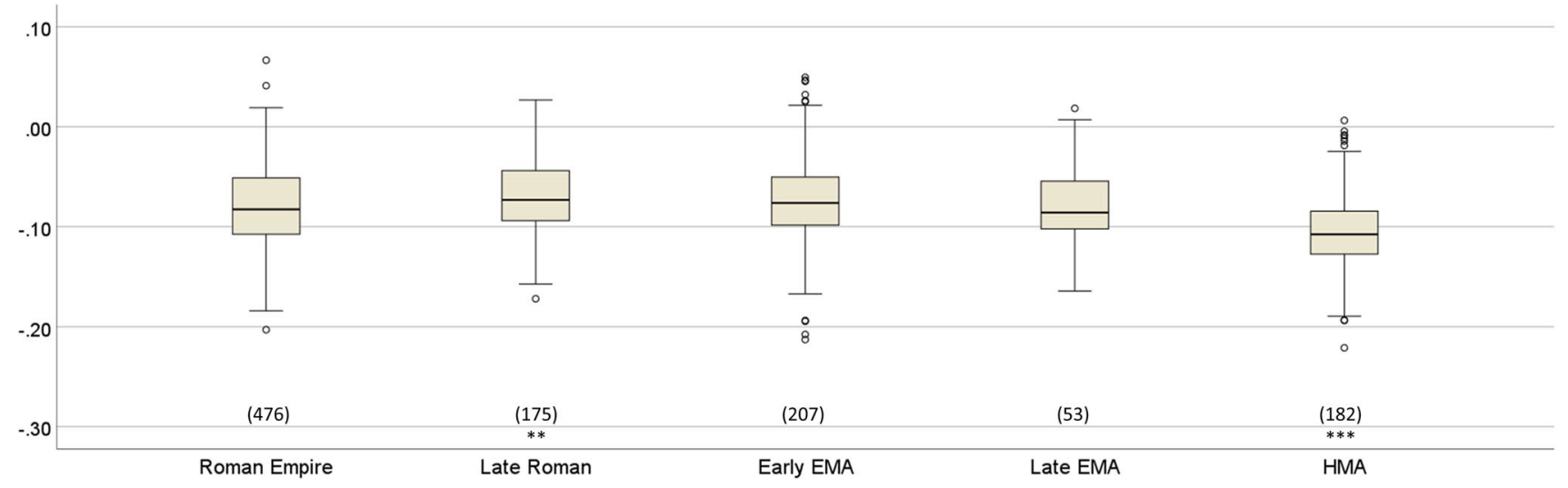

Fig. 11 Box plots showing the $\mathrm{LSI}_{10}$ values of pig postcranial width measurements, divided by period. In brackets, number of measurements. $P$ values are reported (an alpha value of 0.05 is used to assess

are mainly from those sheep/goat postcranial bones for which both species are difficult to tell apart (for instance, not metapodials) and, in these cases, goats would tend to be slenderer than sheep, so length patterns would have been more affected than widths. Our data, however, shows similar trends for both axes in all periods between the Roman times and the Early Middle Ages, with the exception of the High Middle Ages, when we document an increase in the average length size. As we will argue later, we believe that this difference is perhaps due to a greater presence of castrated sheep in the high medieval sample, rather than to a larger number of goats.

Sheep and sheep/goat postcranial width $\mathrm{LSI}_{10}$ values have been plotted in histograms in Fig. 9, arranged according to geographical regions. Roman sheep show a very homogenous size in Augusta Raurica, North Switzerland and Alsace and Jura, with the three groups having similar average values for this period. The histograms for the first two, however, seem to be slightly skewed (North statistical significance): $* * *$, very significant (alpha value $\leq 0.001$ ); $* *$, highly significant (alpha value $\leq 0.01$ ); * significant (alpha value $\leq 0.05$ )

Switzerland towards smaller values and Augusta Raurica towards larger values), perhaps in relation to different sex ratios. We attempted to establish sheep sex ratios for these Roman groups based on metrical data; however, only Augusta Raurica yielded a sample size large enough and is presented in Fig. 10. The histogram bars, again skewed towards the right of the graph, suggest that a large part of the sheep present at the site in Roman times might have been males.

Going back to Fig. 9, a very slight increase of the average is visible for Augusta Raurica in the Late Roman period, with a clearer reduction in sheep size for the early early medieval phase in the same site, although size range remained unchanged. Contemporary sheep from other northern Swiss regions, however, show similar average values to the Roman ones. The reduction of sheep size is more visible for the later periods, with a clear decrease in the average values in the late Early Middle Ages both in the region of Basel and in other northern areas in Switzerland, and a 


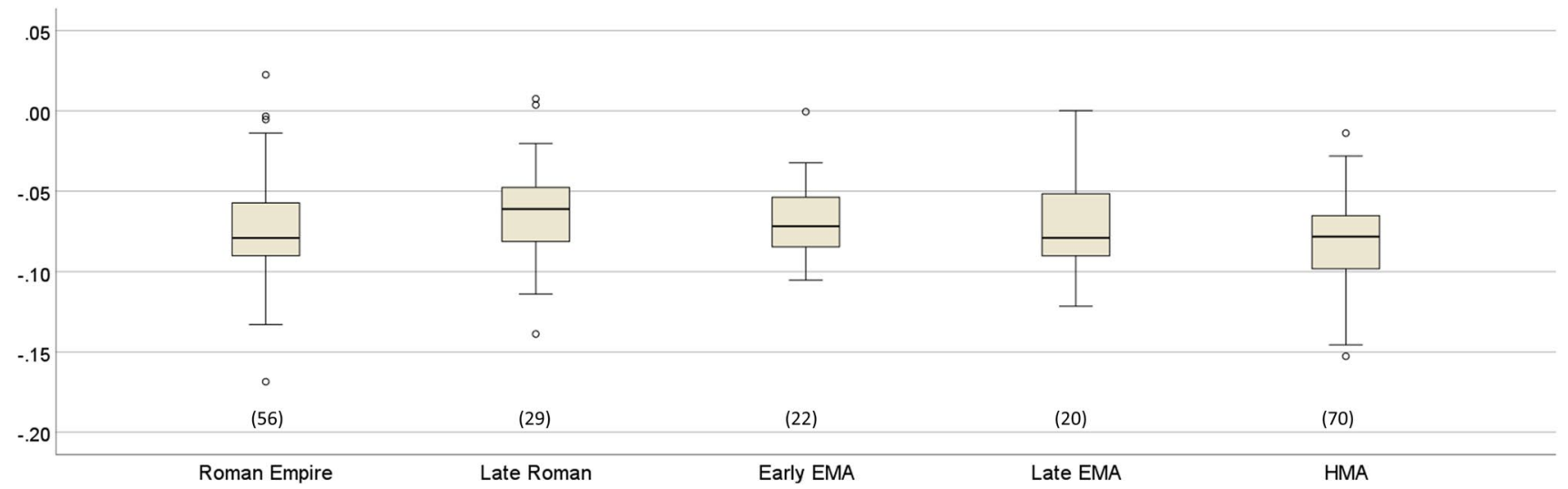

Fig. 12 Box plots showing the $\mathrm{LSI}_{10}$ values of pig postcranial length measurements, divided by period. In brackets, number of measurements

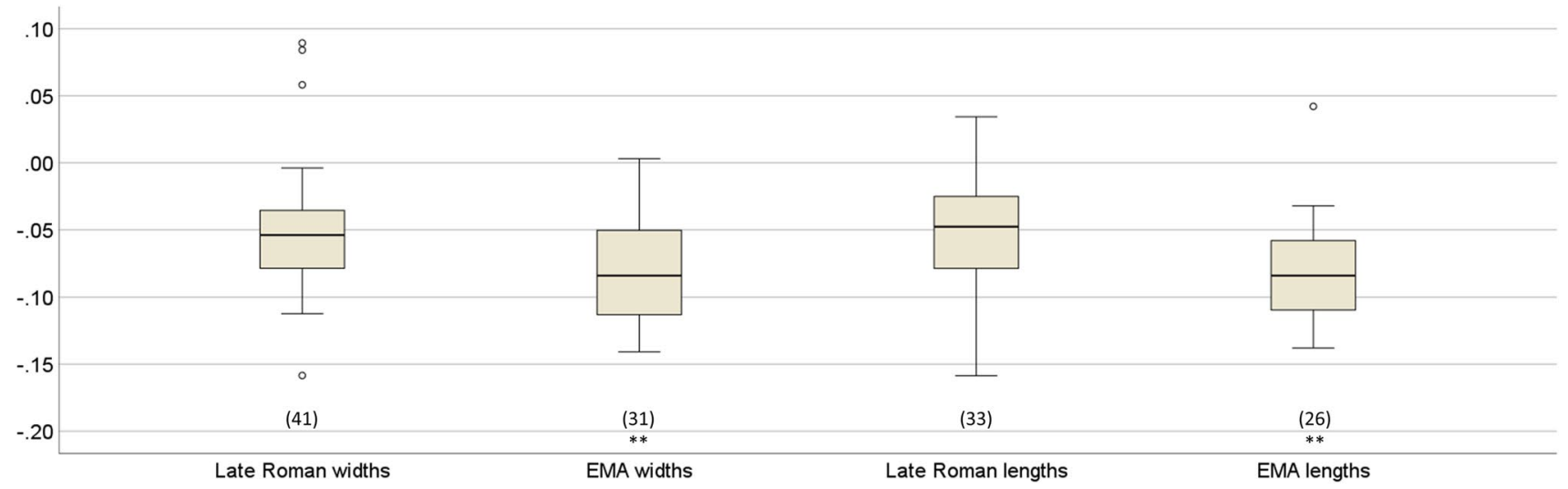

Fig. 13 Box plots showing the $\mathrm{LSI}_{10}$ values of pig lower teeth measurements, divided by period. In brackets, number of measurements. $P$ values are reported (an alpha value of 0.05 is used to assess statistical significance): $* * *$, very significant (alpha value $\leq 0.001) ; *$, highly significant (alpha value $\leq 0.01$ ); $*$ significant (alpha value $\leq 0.05$ )

value $\leq 0.01$ ); $*$ significant (alpha value $\leq 0.05$ ). Effect size: small effect if smaller than 0.1 , small to medium if between 0.1 and 0.3 , medium to high if 0.3 to 0.5 , and very high if above 0.5 pairwise comparisons for pig biometrical data. $P$ values are reported (an alpha value of 0.05 is used to assess statistical significance). $* * *$, very significant (alpha value $\leq 0.001$ ); **, highly significant (alpha

Postcranial measurements

Roman Empire-Late Roman
Late Roman-early EMA
Early EMA-late EMA
Late EMA-HMA

Teeth

$\begin{array}{ll} & \begin{array}{l}\text { Teeth width } \\ \text { Observed }\end{array} \\ \text { Late Roman-EMA (all periods) } & \text { Decrease }\end{array}$

Postcranial widths

Observed

Increase

Very slight decrease

Slight decrease

Decrease

$\begin{array}{ll}\text { Sig } & \text { Effect size } \\ 0.004 * * * & 0.11 \\ 0.459 & 0.03 \\ 0.303 & 0.06 \\ 0.000 * * * & 0.29\end{array}$

Postcranial lengths

$\begin{array}{lll}\text { Observed } & \text { Sig } & \text { Effect size } \\ \text { Increase } & 0.099 & 0.17 \\ \text { Slight decrease } & 0.332 & 0.13 \\ \text { Slight decrease } & 0.58 & 0.08 \\ \text { Similar } & 0.286 & 0.11\end{array}$

Late Roman-EMA (all periods)
Sig

$0.005^{* *}$
Teeth lengths

Observed

Decrease
Sig

$0.007 * *$
Effect size

0.31 


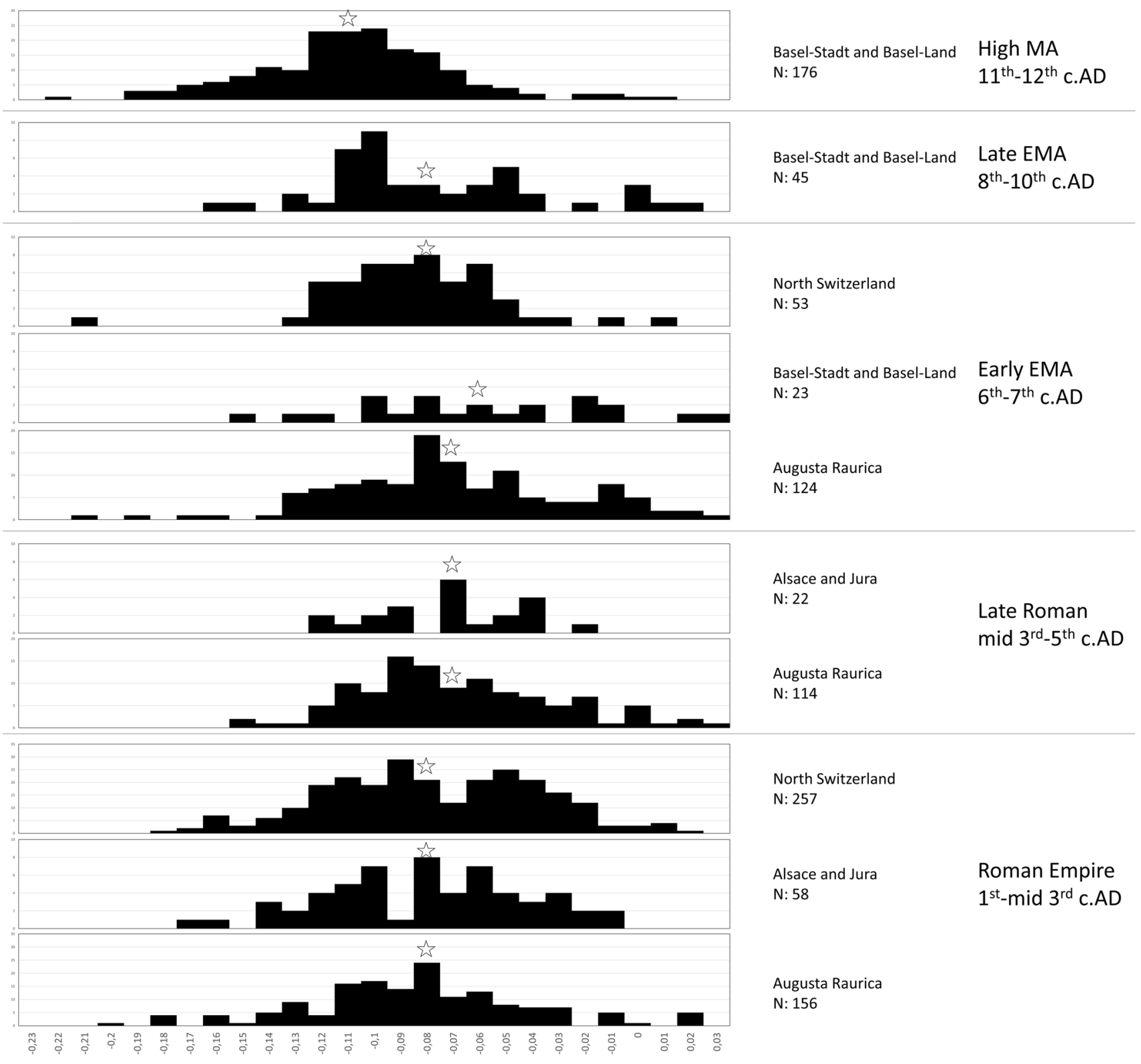

Fig. 14 Histograms with LSI $_{10}$ values of pig postcranial width measurements, by period. Different sites have been grouped in larger regions (except Augusta Raurica, which is shown by its own), and only those with $N>20$ are shown. The star symbols show the average of each group

further, more abrupt decrease in the high medieval period, for which only data from Basel-Stadt and Basel-Land are representative in terms of sample size. Overall, the clearest decrease seems to happen after the eighth century.

\section{Pig}

Supplementary Material SM6 shows the number of pig measurements used in our analysis. Contrary to cattle and sheep, an attempt to use teeth data has been possible in the case of pig, although only between the Late Roman and the Early Middle Ages groups. Periods with a small sample size (less than $N=10$ ) have been excluded (this is the case for teeth measurements dated to the Roman Empire and the High Middle Ages).

Figures 11, 12, and 13 show the evolution of $\mathrm{LSI}_{10}$ values (postcranial widths and lengths, and lower teeth measurements, respectively) in box plots. Postcranial widths show a size increase between the Roman Empire and Late Roman times, highly significant according to the statistical analysis (Table 4). Pig postcranial width measurements tend to decrease in size in the periods afterwards, although only slightly, and in fact, the statistical analysis did not show any statistical significance for this decrease in the early and late 
Early Middle Ages. Visually, the decrease is more notable for the High Middle Ages, and this change has proven to be very highly statistically significant. Effect sizes are small to medium. The patterns are quite similar for the average values of pig postcranial lengths, although, in this case, the changes have not been statistically significant, perhaps due to a reduced sample size. Pig teeth, on the other hand, show a clear size decrease of both lengths and widths between the Late Roman times and the Early Middle Ages, also highly significant according to the statistical analysis despite a relatively small sample size, while effect sizes are medium to high.

Comparisons of pig postcranial width measurements according to geographic regions are shown in the histograms in Fig. 14. This figure shows little variation in the average values of the different groups across time. A very slight size increase can be suggested in Late Roman times in Augusta Raurica and Basel-Stadt and Basel-Land. Smaller average values are clearly visible only for this region during the High Middle Ages. The overall impression, however, is of continuity and homogeneity of pig measurements throughout the Roman and early medieval periods.

As mentioned earlier, our analysis has included individuals identified morphologically as domestic pig or either wild boar or domestic pig, but not those recognised as wild boar. Given the difficulty of separating the two species based on morphological criteria, and the overlap that may occur between them in biometric terms, it is likely that some wild boars are present in the previous graphs. It is however difficult to ascertain in what proportion, especially since wild boar measurements were not included, while they could have been used for comparison. We can only attempt an indirect approach: since our standard values derive from a male wild boar from the same geographic region, it can be suggested that values as large or larger than 0.0 might have belonged to wild boars, but a clear division between the wild and domestic forms is not possible (individuals below 0.0 but still in the larger spectrum might have been female wild boars or male pigs, for instance). The vast majority of the data is well below the values of the standard, suggesting that our sample is probably predominated by domestic pigs. An attempt to understand the ratios between pig and wild boar using metrical data is presented in the Supplementary Materials (Supplementary Material SM3): following Albarella and Payne (2005: 598), width and length measurements of lower third molars and astragalus GLl have been used. A clear distinction between the two species is not visible, either because our samples are mostly one species (most likely domestic pig), or because the possible wild boars under "Sus sp." are of a size similar to domestic pigs.

\section{Discussion}

With slight differences and nuances, as described above, size changes of the three livestock species analysed here show a relatively homogenous pattern of size increase between the Roman Empire and the Late Roman period, followed by a continuous decrease in size during the Early and High Middle Ages. These results confirm, to a certain extent, the general patterns suggested by previous research that was based on smaller sample sizes (Breuer et al. 1999 and 2001; Marti-Grädel 2012 and 2013; Frosdick 2014); however, these previous works did not count with enough evidence for the period between the fourth and the seventh c., while our paper does, providing a greater accuracy in the timings of these changes. Having observed these patterns, we need to discuss the reasons for them.

\section{What are the possible factors behind the observed size changes?}

\section{Age and sex}

As mentioned earlier, changes in the kill-off patterns may be behind changes in animal size and therefore, age profiles must be considered in the discussion of biometrical data. However, we have selected to use measurements that are less dependent on age and, moreover, unfused elements have not been used in our analysis. Therefore, although a certain growth could happen even after fusion, it seems unlikely that the size changes that we have observed are related to changes in the kill-off patterns. In any case, the kill-off patterns seem to lean towards an overall older age of domesticates at the moment of death in the Early Middle Ages (Frosdick 2014; Akeret et al. 2019); this would mean that, if changes in age ratios were behind the changes in size, early medieval animals would be larger than the Roman ones, and this is clearly not the case.

An important issue to consider is whether the observed size changes might correspond to changes in the sex ratios of cattle, sheep, and pig, because all of these livestock species exhibit some degree of sexual dimorphism: in these species, males tend to be larger than females, and castrates, of special importance in cattle and sheep husbandry, because of their enhanced traction power - in the case of oxen - and wool production and qualities - in the case of wethers - tend to be more slender because of their delayed epiphysary fusion. In other words, is the observed early medieval size decrease a product of a real "shrinking" of the general populations of these species, or is it because there are more females in comparison to males and castrates? 
Morphological characteristics (such as the shape of pig canines and their alveoli, or the shape of the pelvis) can be used to determine sex; however, this type of data is scarce in our dataset and therefore inconclusive. Biometrical analysis is possibly our best chance to reconstruct sex ratios of the livestock species considered here, although in this case the sample size of the most sexually dimorphic measurements is too small, particularly for sheep and pig. Furthermore, this type of analysis is complicated by the difficulty of distinguishing sheep from goat and pig from wild boar.

Regarding cattle, the observed size decrease after the Late Roman period might have been related to a decrease in the proportion of oxen used for agricultural purposes. Castration delays the age at which epiphyses fuse to the diaphysis in long bones, which affects mostly length measurements, resulting in animals that are notably taller, but not necessarily more robust. Our biometrical analysis shows that size changes happened similarly in both axes of bones (lengths and widths), so the evidence does not support the idea of a size change related to a change in castration patterns. The specific biometric analysis looking at cattle sex ratios (Fig. 5), however, has provided interesting results, suggesting that the progressive size decrease observed for cattle after the Late Roman times is not related to changes in sex ratios but, rather, a true size decrease of cattle populations.

The change between the Roman times and the Late Roman times may suggest a small increase in the proportions of female cattle, and possibly, smaller presence of castrates. Such a shift towards more mixed-sex cattle populations would make sense in an economic context in which cattle's secondary products (mainly traction and dairy) would have an increased importance compared to meat. Indeed, mixed farming is suggested to be one of the main characteristics of early medieval rural societies, as opposed to the specialised Roman agrarian practices (e.g. Kron 2002; Crabtree 2010; O'Connor 2010a, 2010b and 2014; Hammon 2011; Rizetto et al. 2017; Akeret et al. 2019). Ancient writers like Julius Cesar, Strabo, Tacitus, Pliny the Elder or Poseidonios mentioned that the consumption of milk and butter was a characteristic of Germanic people. From the Late Antiquity onwards, the northern influences became more marked in the area under study and could be one of the factors anticipating the progressive switch to cattle dairy production.

It is also noteworthy that the chronological period with the largest sample size, the Roman Empire, does not show a bimodal distribution, but rather a unimodal one (Fig. 5). There are two possible explanations for this:

1) The sample is predominated by either large females or small males.

2) The sample is composed by a mixture of different cattle types, and therefore, values for females, males, and castrates would significantly overlap.
We believe that the first explanation is highly unlikely, as it would seem to contradict everything that we know about cattle husbandry in Roman times. Evidence from different areas of the Roman Empire (e.g. Lepetz 1995; Méniel 1996; Mariezkurrena 2004; Albarella et al. 2007a; Trentacoste et al. 2021), including Switzerland (Breuer et al. 1999 and 2001), shows that, compared to the Iron Age, Romans put a real effort in improving their cattle, both for feeding beef to an increasing urban and military population, and for using really large oxen for agricultural purposes. Moreover, it seems improbable that one of the two sexes would be so predominant in the sample, as some individuals of the opposite sex would always be present. In other words, a certain skewedness to either side would be expected, rather than the unimodal-Gaussian distribution visible in our earlier graphs (Figs. 5 and 6).

The second explanation is therefore more likely. It would only make sense that, during the Roman Empire, a period in which extensive trade networks allowed for the movement of livestock across all of Europe (e.g. Schlumbaum et al. 2006; Minniti et al. 2014; Colominas \& Edwards 2017), a larger variability in cattle types appeared. It is noteworthy to mention that a large sample of the Roman cattle biometric data used for the analysis of sex comes from Augusta Raurica, a large Roman city that acted as a social, political, and economic centre in the studied region. The demand of cattle (either for meat consumption or for crafts and industry) must have been quite remarkable from such a large urban settlement, so it would just make sense that different types of cattle, perhaps coming from different areas, are found.

\section{Environmental factors}

Animal size and shape may change due to environmental reasons, such as foodstuffs, husbandry techniques, and climate. It is a biological rule (Bergmann's rule - Bergmann 1847) that animals are bigger in colder areas and smaller in warmer areas, and there is indeed some zooarchaeological research suggesting a direct causal relationship between climate change and animal size change in the Pleistocene-Holocene transition (i.e. Davis 1981). But, firstly, it is unclear if climate fluctuations during the Holocene would be sufficient to cause substantial change in animal size, and, secondly, it is not so evident how climate change would directly affect the size of domesticated, farm animals, like the ones being discussed here. In any case, importantly, the size changes discussed in this paper seem to go in the opposite direction to what Bergmann's rule states: Roman animals are large, during what palaeoclimate scholars call the Roman Warm Period (250 BC-AD400) (Joerin et al. 2006; McCormick et al. 2012), and their size decreases during the Late Antique Little Ice Age (sixth-seventh c.) (Burga et al. 2001; Büntgen et al., 2016). Therefore, we believe that climate can be safely 
discarded as the direct cause of the observed livestock size changes.

A link between the introduction of new foodstuffs or new feeding regimes and size change is theoretically possible (Hammond 1960; Widdowson and Lister 1991). Zooarchaeological and historical evidence suggest that, during Roman times, agricultural practices "improved" in order to increase agrarian production, which was largely aimed at a specialisation of the production and at a growing market (e.g. Grant 2004; Groot and Deschler-Erb 2015; Groot 2017; Pigière 2017). One possibility is that intensive $^{7}$ animal husbandry was practised in order to achieve greater productivity. A close control of feeding times and foodstuffs, as well as keeping animals in stables or stys, are possible factors behind livestock size increase in the Roman period. However, some works have suggested that extensive agricultural practices were practised in different parts of the Roman Empire (MacKinnon 2001; Albarella et al. 2019; Lodwick et al. 2020). The extent to which agricultural practices were more or less intensive or extensive (in terms of inputs per unit area) might have varied greatly depending on various factors such as climate, soil, or demographic density, and understanding the particularities of this would require a multidisciplinary approach that is well beyond the scope of this paper. Moreover, both intensive and extensive agricultural practices can theoretically coexist (with intensive irrigation and extensive pasturing of herd animals, for example). In fact, in Switzerland, while some animal stables have been found, and pathological marks on pig feet bones have been interpreted as possible evidence of them being tied with a rope, material culture evidencing that cattle were allowed to graze outside has been identified as well (Deschler-Erb et al. 2002: 168-169). The evidence is still too fragmentary to be able to generalise that Roman animal husbandry practices in the study region were intensive, but they were certainly operated at a large scale, while for the Early Middle Ages, agricultural activities were mainly aimed at self-subsistence, and therefore were carried out at a smaller-scale, like it has been suggested for other European regions (e.g. Henning 2009 and 2012; Crabtree 2010; McCormick et al. 2014; Hamerow et al. 2019 and 2020; Akeret et al. 2019). If less land was being cultivated for crops, then more land would have been available for feeding livestock. These changes after the end of the Roman times might have meant that, in contrast to the previous period, early medieval livestock was more often kept with some degree of freedom for roaming and grazing. In England, for example, early medieval pigs were quite likely taken to woodland areas, to be fed on roots, acorns and beech mast (Albarella 2006:
77). Although slight changes in the size of pigs through time have been described in our analysis above, the relative continuity of pig size between the Late Roman times and the Early Middle Ages (compared to cattle and sheep, which experienced much more marked changes) might reflect interbreeding between the two species, an issue that has been discussed for other early medieval contexts (Albarella et al. 2019). Interbreeding between wild boars and domestic pigs might have been facilitated by such freerange practices. Various pollen analyses in different regions of Europe (e.g. Barceló and Sigaut, 2004; Bowden et al., 2004; Palet, 1999-2000; Wick 2015; Akeret et al. 2019) suggest that, in the Early Middle Ages, there was a reduction of the cultivated areas for cereals, in contrast with an increase of grassland and forests, which may have been used to feed animals. Less controlled feeding and breeding habits, together with a relatively more mobile lifestyle (in terms of seasonal movements or free-range practices, but not in terms of animal trade, as we argue below), are possible explanations behind the size decrease throughout the Early Middle Ages.

Archaeologically, direct evidence for this could be investigated through isotope geochemistry but, at the moment, such study is only underway for our study region. For example, a more herbivorous pig diet might mean a more free-ranged husbandry strategy, as their access to protein would have been limited if not kept in stys. In other European areas, recent research suggests that, in fact, herbivores and omnivores were largely kept free-ranged. In the early medieval northern Iberian Peninsula, for example, isotopic research (García-Collado 2020: 270 and following pages) has highlighted that the diet of livestock only showed the contribution of $\mathrm{C}_{4}$ plant additions occasionally (these are interpreted as possible foddering with millets when animals were kept in the proximity of households), as well as isotopic values very close to those of herbivores for pig. This type of studies in isotope geochemistry looking at changes in animal husbandry practices for the period considered in this paper can be considered still somewhat in its infancy. At the moment, one can only speculate that a general turn of the scale of animal husbandry (and farming) from large to small after the collapse of the Roman Empire and the fragmentation of early medieval economies (phenomena that have been otherwise more thoroughly investigated by historians and landscape and settlement archaeologists - e.g. Wickham 2005 and 2009; Hodges 2012; Quirós Castillo 2013; Bianchi 2015), led to changes in livestock feeding practices, and these, in turn, were at least partly responsible of their size decrease.

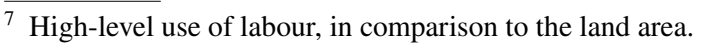




\section{Genetic factors}

A genotypic size and shape change would happen through a genetic change, either through the introduction of foreign animals or through the selection of local ones that meet specific criteria chosen by the breeders. Zooarchaeologically (and without aDNA analyses), genetic modification can be detected by looking at teeth biometry, since these are less plastic and less affected by environmental factors than postcranial bones (Payne and Bull 1988; Albarella 2002). Too few tooth measurements were unfortunately available for cattle and sheep. Teeth pig measurements were also scarce, but the results shown in Fig. 13 suggest that the decrease in pig size between the Late Roman times and the Early Middle Ages was (at least partly) due to a phenotypic change. The decrease in size of both length and width teeth measurements suggests that this size decrease was probably not related to the shortening of the snout, a characteristic that seems to have been developed in the Modern Era (Albarella et al. 2006; Grau-Sologestoa and Albarella 2019). However, the teeth-related evidence for size change is still limited and, therefore, these ideas should be considered mere hypotheses that would need to be researched further in future studies. To this aim, it would be really interesting to have teeth biometric data recorded and reported more often in future zooarchaeological publications.

Smaller animals might have been introduced, from non-Romanised areas in which livestock size did not increase significantly since the Iron Age (this is the case, for example, of Germania Magna - e.g. Teichert 1984); however, we believe that such introductions might have occurred only seldom. The decrease in animal size during the early medieval period is a phenomenon that is documented in many regions of Europe (Yvinec 1991; Stephan 2008; Rehazek 2010; O'Connor 2010a; Hammon 2011; Holmes 2014; Grau-Sologestoa 2015a; Salvadori 2015; Rizzetto et al. 2017) and, therefore, we could hypothesise that, if the smaller size were due to the introduction of smaller animals, this would have needed to be done at a large scale, in a way that it would have affected livestock in most of Europe. Considering that, with the collapse of the Roman Empire, European trade networks declined at least during the earliest centuries of the Early Middle Ages (e.g. Wickham 2005 and 2009; Hodges and Bowden 1998; Hodges 2012; Effros and Moreira 2020), it seems unlikely that inter-regional livestock trade could have continued happening. Livestock exchange probably happened at a smaller, more localised scale. In such situation, a much more likely scenario is that some degree of genetic bottleneck or degeneration might have occurred (for example, through several generations of livestock breeding within the same genetic pool). Interbreeding and increased homozygosity leads to a decrease in size (Baker et al. 1945; Sutherland and Lush 1962; Doekes et al. 2019), and it may also reduce fertility and produce a decrease in milk, fat, and protein yields (Pryce et al. 2014).

Another possibility is that early medieval breeders might have deliberately sought for smaller animals and selectively chosen them for breeding. If that was the case, we must consider what are the implications of the observed size changes in relation to the historical context.

\section{Size changes and their relation to socio-economic and political upheavals}

In zooarchaeological literature, periods of animal size increase are commonly interpreted as the results of periods of experimentation in breeding and management practices, intensification, enhanced trade of animals, etc. (e.g. in Roman times - i.e. Lepetz 1995 and 1996; Peters 1998; Forest and Rodet-Belarbi 2002; Kron 2002; Grau-Sologestoa 2015a; Colominas and Saña 2010; Trentacoste et al. 2021 - or in post-medieval times - i.e. Davis and Becket 1999; Thomas 2005; Grau-Sologestoa and Albarella 2019), all within the aim of "improving" livestock and productivity in response to factors such as an increased demand of animal products, demographic increase, or the extension of trade networks. Larger, "improved" animals provide a larger meat yield per head, faster maturation rates, and increased strength for traction, all of the aspects of key importance in the context of an economy strongly oriented towards the market, such as the Roman one. In fact, Romans perceived the keeping of unimproved animals as a sign of primitiveness, as suggested by historical sources such as Caesar (Gallic War IV, 2) and Tacitus (Germania 5), and it was a significant element of cultural differentiation for both the Romans and the indigenous populations of north-western Europe (Albarella 2007b: 398).

On the other hand, scholars are much more unclear when it comes to interpreting periods of animal size decrease, such as the one documented by this research. The most logical reasoning is that the same factors as the ones described for periods of size increase might have occurred, though in inverse direction (i.e. less labour, isolation, and/or stagnation). However, with this argumentation that inevitably leads to thinking in negative terms, it is tempting to think of this decrease as "degeneration" of livestock types (as opposed to "improvement") and, in a context like the transition between the Late Antiquity and the Early Middle Ages, traditionally already connoted with negative notions (it is frequently interpreted as a period of crisis or collapse and often called the "Dark Ages" - i.e. Ward-Perkins 2006; Hodges 2012; Bull 2005), one might question the ability of early medieval farmers to keep their livestock in good conditions. However, "the assumption that they (larger animals) had to be 
preferred at all times $(\ldots)$ relies more on modern theories of economic maximization than on the actual variables that affected choices made by past rural communities" (Rizzetto et al. 2017:548).

The size decrease of livestock during early medieval times surely indicates a form of cultural and economic change, but not necessarily for the worse. We must bear in mind that smaller animals might have some advantages over larger ones and that farmers might have preferred and chosen to keep small animals. Henning (2012) suggests that smaller cattle was more appropriate to plough lands following the three-field system. Moreover, smaller livestock probably required less labour and food, and therefore might have been cheaper for the farmer. For instance, two of the smallest modern European cattle breeds, the Dexter ${ }^{8}$ and the Prespa (Grunenfelder 2006 and 2014), are considered to provide a good relation between input and output (milk for the first and meat for the second); they are both very well adapted to local conditions and are suitable for low input agriculture. The Prespa cattle are praised for their longevity and resistance to diseases, while the Dexter are very efficient grazers that thrive on poor land. Observations on modern miniature cattle breeds have also pointed out that small cattle are more suitable for small plots of land, they are more docile and easier to handle and produce less wear and tear on equipment, and the costs for housing and fencing tend to be reduced (Boden 2008). Modern small-sized sheep breeds, such as the Soay, the Shetland, or the Ouessant, are also considered to be hardy, agile, and resistant to adverse conditions and diseases. ${ }^{9}$ For small-sized pigs, their suitability for extensive husbandry systems and transhumance has been pointed out, together with their versatility, hardiness, and need for low labour, for instance in Corsica and Sardinia (Albarella et al. 2007b and 2011). All of the above are characteristics that might have made smaller animals desirable for early medieval husbandry.

As discussed above, we think that the observed size decrease can be explained by the following factors, or rather, more likely, by a combination of them:

1) More limited livestock trade and, as a result, a reduced gene pool,

2) Smaller-scaled and non-specialised animal husbandry practices and, therefore, less control over feeding and breeding, and perhaps,

\footnotetext{
${ }^{8}$ See for example, the web pages of the American Dexter Cattle Association: https://dextercattle.org/, or of the Dexter Verband Deutschland: https://www.dexter-verband-deutschland.de/.

9 See, for example, the information on Soay sheep at the Rare Breeds Survival Trust: https://www.rbst.org.uk/soay, the Shetland Sheep Society: https://www.shetland-sheep.org.uk/, or the Ouessant Sheep Society: https://www.ouessantsheep.org.uk/.
}

3) Increased proportions of female animals over males (and possibly, smaller presence of castrates).

All of these factors suggest that the smaller size of farm animals was a consequence of the adaptation of husbandry practices (including breeding, keeping, feeding, or herd composition) to wider social, economic, and political transformations. In turn, keeping smaller livestock might have been an advantage in the light of such upheavals.

The new political and economic conditions brought about by the collapse of the socio-political frame that directed the Roman economic system implied a radical reconfiguration of agrarian practices and food production. The small, self-sufficient settlements that replaced specialised agricultural villas, Roman towns, and market centres engaged in a less specialised form of husbandry (e.g. O'Connor 2014; Rizzetto et al. 2017; Akeret et al. 2019). In fact, size decrease is only one of the various types of zooarchaeological evidence for this period that suggest a turn into a more self-sufficient, mixed form of animal husbandry. Other zooarchaeological evidence for this shift are as follows: the increasing predominance of medium-sized animals instead of cattle (for example, sheep/goat in Spain - Grau-Sologestoa 2015b; Britain - O'Connor 2010b and 2014, Rizzetto et al. 2017; and in Switzerland both sheep/goat for wool production Frosdick 2014, Akeret et al. 2019: 83; and pig as a marker of social status - Marti-Grädel 2012), a turn into more mixed kill-off patterns (e.g. O'Connor 2010a, 2010b and 2014; Rizzetto et al. 2017; Grau-Sologestoa 2015b), or the mixed herd structure suggested by the sex analysis discussed above.

Two more aspects need to be discussed here. First, the changes observed in the size of pig are less obvious than for cattle and sheep, although the pig sample size seems to be large enough. The reasons behind this might be twofold (and possibly occurring in parallel). On the one hand, if, as mentioned above, medieval pigs were kept free-range, interbreeding with wild forms might have become more frequent, resulting in relatively large pigs. Our analysis has shown a greater decrease of pig teeth size than of postcranial bones; the smaller teeth in relation to post-cranial bones are typical of wild boar (Albarella et al. 2019: 28; Tecce and Albarella 2020: 121), so this difference suggests that pigs acquired more wild-boar-like characteristics, and therefore, supports the hypothesis of hybridisation or interbreeding between the two species, facilitated by being kept free-range. On the other hand, it might be that large pigs served well the purposes of early medieval communities in their way to adapt to the new social and economic circumstances: in an economy in which cattle and sheep, the other two main livestock species, are kept mainly for secondary purposes (traction, milk, and wool), pigs might have gained relevance as the most important source for meat production. 
Last, although the later periods are not the main focus of this paper, we would like to discuss, albeit briefly, that our evidence shows that livestock size kept decreasing in the eighth-twelfth centuries, and other works have suggested that this tendency only reverted after the fifteenth century (Marti-Grädel 2012; Marti-Grädel and Hüster-Plogmann 2014: 75). The High Middle Ages in Switzerland saw the expansion of arable land, the intensification of agriculture and manuring, and the occupation of marginal, mountainous areas of the Jura and the Alps (Niffeler 2014); it is therefore quite puzzling that livestock size did not recover in such a context of agrarian growth. Although our data for these later centuries is still limited, we can suggest, as a hypothesis, that the process of intensification might have affected mainly agricultural practices, and less so animal husbandry. Moreover, our sample is dominated by urban sites (e.g. Basel, where cattle seem to be small females?), while the few large specimens are found in castles (e.g. Altenberg, with probably a high proportion of measurements of oxen in the sample) and rural settlements. A greater importance of wool production might be suggested for the High Middle Ages, based on the increase of the sheep postcranial lengths, but not widths, possibly indicating a larger proportion of castrates, that are known to be good wool producers. High proportions of sheep/goat occur mainly in urban sites, suggesting that they were centres for textile production.

\section{Conclusion}

The results of the present study show that livestock improvement continued well into the Late Roman times (mid third-fifth centuries AD), despite this being a period of instability and profound changes in settlement patterns for the study region, which, due to its proximity to the limes, was at the centre of some of the earliest incursions of Germanic tribes into the Roman Empire (e.g. Schwarz 2011). Our results suggest that this instability did not have immediate negative consequences in the size of domestic animals. In fact, it appears that the size of the three domesticates decreased significantly only after the sixth century AD, and continued to do so at least until the High Middle Ages.

The discussion of the results of our analysis has highlighted three possible concomitant factors behind this observed size decrease during the Early Middle Ages: genetic change, less control over feeding and breeding, and changing patterns of herd sex ratios. In our opinion, these changes should be seen as an efficient adaptation of animal husbandry strategies to broader transformations of agricultural practices, such as the limitation of trade, the smallerscaled and mixed types of agriculture, and the turn to a more self-sufficient economy, rather than a degeneration of animal husbandry practices after the collapse of the western Roman Empire.

This paper provides a comprehensive meta-analysis of biometrical data of cattle, sheep and pig archaeological remains with a long-term perspective (between the Roman times and the High Middle Ages, with a special attention to the period between the Late Roman and the early medieval times), and at a large regional scale (Switzerland and adjacent regions of France). The relatively large sample size and chronological precision of the different periods used in this analysis, have allowed a thorough investigation of the changes in size that the three commonest domestic animal species underwent during this key period of economic, social and political transformations. Understanding the nature of these changes, the reasons behind them, and their timing, are of key importance to comprehend both the consequences of the collapse of the Empire and the construction of early medieval economies.

Future studies could fruitfully explore these processes by looking at genetic changes (through aDNA analysis), as well as feeding patterns and degrees of livestock mobility (through stable isotope geochemistry), or residue analysis to look at dairy consumption. Moreover, the current era of digital data and globalised research should facilitate interregional comparisons and similar biometrical analyses at a much broader scale.

Supplementary Information The online version contains supplementary material available at https://doi.org/10.1007/s12520-021-01426-w.

Acknowledgements This project has received funding from the European Union's Horizon 2020 research and innovation programme under the Marie Skłodowska-Curie grant agreement No 793221. The idea of this paper was conceived and developed by IGS and SDE. Data analysis was carried out by IGS. A first draft of the paper was written by IGS and then benefitted from comments by SDE, EMG, FG, and BS. The original biometrical data on which this analysis is based were either obtained from published literature or, in their largest part, were collected and owned by SDE, EMG, FG, BS, and IGS.

We would like to thank the three anonymous reviewers for their useful comments to improve the initial submission.

Funding Open access funding provided by University of Basel.

Data availability The whole biometrical dataset is available here: http:// doi.org/10.5281/zenodo.4707131

Open Access This article is licensed under a Creative Commons Attribution 4.0 International License, which permits use, sharing, adaptation, distribution and reproduction in any medium or format, as long as you give appropriate credit to the original author(s) and the source, provide a link to the Creative Commons licence, and indicate if changes were made. The images or other third party material in this article are included in the article's Creative Commons licence, unless indicated otherwise in a credit line to the material. If material is not included in the article's Creative Commons licence and your intended use is not permitted by statutory regulation or exceeds the permitted use, you will 
need to obtain permission directly from the copyright holder. To view a copy of this licence, visit http://creativecommons.org/licenses/by/4.0/.

\section{References}

Akeret Ö, Deschler-Erb S, Kühn M (2019) The transition from Antiquity to the Middle Ages in present-day Switzerland: the archaeobiological point of view. Quat Int 499(A):80-91

Albarella U (2002) Size matters: how and why biometry is still important in zooarchaeology. In: Dobney K, O'Connor T (eds) Bones and the man. Oxbow Books, Oxford, Studies in honour of Don Brothwell, pp 51-62

Albarella U (2006) Pig husbandry and pork consumption in Medieval England. In: Woolgar C, Serjeantson D, Waldron T (eds) Food in Medieval England: Diet and Nutrition. Oxford University Press, Oxford, pp 73-87

Albarella U (2007) The end of the Sheep Age: people and animals in the Late Iron Age. In: Haselgrove C, Moore T (eds) The later Iron Age in Britain and beyond. Oxbow Books, Oxford, pp 389-402

Albarella U, De Grossi MJ, Minniti C (2019) Urban pigs: dietary, cultural and landscape changes in $1^{\text {st }}$ millennium AD Rome. In: Peters J, McGlynn G, Goebel V (eds) Animals: cultural identifiers in ancient societies? Documenta Archaeobiologiae 15. Verlag Marie Leidorf, Rahden/Westf., pp 17-30

Albarella U, Dobney K, Rowley-Conwy P (2006) The domestication of the pig (Sus scrofa): new challenges and approaches. In: Zeder MA, Bradley DG, Emshwiller E, Smith DD (eds) Documenting domestication. University of California Press, Berkeley, New genetic and archaeological paradigms, pp 209-227

Albarella U, Johnstone C, Vickers K (2007a) The development of animal husbandry from the Late Iron Age to the end of the Roman period: a case study from South-East Britain. J Archaeol Sci 20:1-21

Albarella U, Manconi F, Trentacoste A (2011) A week on the plateau: pig husbandry, mobility and resource exploitation in central Sardinia. In: Trentacoste A (ed) Albarella U. Oxbow Books, Ethnozooarchaeology. The present and past of human-animal relationships. Oxford, pp 143-159

Albarella U, Manconi F, Vigne J-D, Rowley-Conwy P (2007b) Ethnoarchaeology of pig husbandry in Sardinia and Corsica. In: Albarella U, Dobney K, Ervynck A, Rowley-Conwy P (eds.) Pigs and humans. 10,000 years of interaction. Oxford: Oxford University Press, pp. 285-307

Albarella U, Payne S (2005) Neolithic pigs from Durrington Walls, Wiltshire, England: a biometricaldatabase. J Archaeol Sci 32:589-599

Baker GA, Mead SW, Regan WM (1945) Effect of inbreeding on the growth curves of height at withers, weight, and heart girth of Holstein females. J Dairy Sci 28:607-610

Barceló M, Sigaut F (2004) The making of feudal agricultures? Brill, Leiden

Bemmann J, Quast D (2008) Rom und die Barbaren. Europa zur Zeit der Völkerwanderung. Bonn: Hirmer Verlag GmbH

Berger L (2012) Führer durch Augusta Raurica. Schwabe, Basel

Bergmann C (1847) Über die Verhältnisse der Wärmeökonomie der Thiere zu ihrer Grösse. Göttinger Studien 3(1):595-708

Bianchi G (2015) Analyzing fragmentation in the Early Middle Ages: the Tuscan model and the countryside in the centralnorthern Italy. In: Gelichi S, Hodges R (eds) New Directions in Early Medieval European Archaeology: Spain and Italy Compared. Essays for Riccardo Francovich. HAMA 24. Brepols, Turnhout
Boden DW (2008) Miniature cattle: for real, for pets, for production. Journal of Agricultural and Food Information 9(2):167-183. https://doi.org/10.1080/10496500802174036

Bowden W, Lavan L, Machado C (2004) Recent research on the late antique countryside. Brill, Leiden

Breuer G, Rehazek A, Stopp B (1999) Grössenveränderungen des Hausrindes. Osteometrische Untersuchungen grosser Fundserien aus der Nordschweiz von der Spätlatenzeit bis ins Frühmittelalter am Beispiel von Basel, Augst (Augusta Raurica) und Schleitheim-Brüel. Jahresberichte Aus Augst Und Kaiseraugst 20:207-228

Breuer G, Rehazek A, Stopp B (2001) Veränderung der Körpergrösse von Haustieren aus Fundstellen der Nordschweiz von der Spätlatènzeit bis ins Frühmittelalter. Jahresberichte Aus Augst Und Kaiseraugst 22:161-178

Bull M (2005) Thinking medieval. An introduction to the study of the Middle Ages. Palgrave MacMillan, London

Büntgen U, Myglan VS, Ljungqvist FC, McCormick M, Di Cosmo N, Sigl M, Jungclaus J, Wagner S, Krusic PJ, Esper J, Kaplan JO, de Vaan MAC, Luterbacher J, Wacker L, Tegel W, Kirdyanov AV (2016) Cooling and societal change during the Late Antique Little Ice Age from 536 to around 660 AD. Nat Geosci 9:231-236

Burga CA, Perret R, Zoller H (2001) Swiss localities of early recognized Holocene climate oscillations - characterization and significance. Vierteljahrsschrift Der Naturforschenden Gesellschaft in Zürich 146:65-74

Christie N (2009) The fall of the Western Roman Empire: archaeology, history and the decline of Rome. Bloomsbury, London

Cohen J (1988) Statistical power analysis for the behavioural sciences, 2nd edn. Academic Press, New York

Colominas L, Edwards CJ (2017) Livestock trade during the Early Roman Period: first clues from the trading post of Empúries (Catalonia). Int J Osteoarchaeol 27:167-179. https://doi.org/10. 1002/oa.2527

Colominas L, Saña M (2010) Animal husbandry in the North-East of Catalonia from the 1st to the 5th century AD: improvement and importation. In: Ortega JM, Escriche C (eds) I Jornadas de Arqueología Medieval en Aragón. Balances y novedades, Teruel

Crabtree P (2010) Agricultural innovation and socio-economic change in early medieval Europe: evidence from Britain and France. World Archaeol 42:122-136

Davis SJM (1981) The effects of temperature change and domestication on the body size of Late Pleistocene to Holocene mammals of Israel. Paleobiology 7(1):101-114

Davis SJM (1996) Measurements of a group of adult female Shetland sheep skeletons from a single flock: a baseline for zooarchaeologists. J Archaeol Sci 23(4):593-612

Davis SJM (2008) Zooarchaeological evidence for Moslem and Christian improvements of sheep and cattle in Portugal. J Archaeol Sci 35:991-1010

Davis SJM, Beckett JH (1999) Animal husbandry and agricultural improvement: the archaeological evidence from animal bones and teeth. Rural Hist 10(1):1-17

Deschler-Erb S (2017) Animal husbandry in Roman Switzerland: state of research and new perspectives. Eur J Archaeol 20(3):416-430. https://doi.org/10.1017/eaa.2017.18

Deschler-Erb S., Schibler J., Hüster-Plogmann H. (2002) Viehzucht, Jagd und Fischfang. In: Flutsch L, Niffeler U, Rossi F (eds.) (2002) Römische Zeit - Età romana, SPM V. Basel, pp. $165-171$

Doekes HP, Veerkamp RF, Bijma P, de Jong G, Hiemstra SJ, Windig JJ (2019) Inbreeding depression due to recent and ancient inbreeding in Dutch Holstein-Friesian dairy cattle. Genet Sel Evol 51:54. https://doi.org/10.1186/s12711-019-0497-z 
Effros B, Moreira I (eds) (2020) The Oxford Handbook of the Merovingian World. Oxford University Press, Oxford

Fernández C, Fuertes N (2007) La romanización del noroeste de la Península Ibérica y las modificaciones en la presencia, uso y consumo de mamíferos. In: Jorge SO, Bettencourt AMS, Figueiral I (eds.), A concepçao das paisagense e dos espaços na Arqueologia da Península Ibérica. Actas do IV Congresso de Arqueologia Peninsular, Promontoria Monográfica, 8. Centro de Estudos de Patrimonio - Universidade do Algarve, Portugal, pp. 207-217

Flutsch L, Niffeler U, Rossi F (eds.) (2002) Römische Zeit - Età romana, SPM V. Basel: Verlag Schweizerische Gesellschaft für Ur- und Frühgeschichte

Forest V, Rodet-Belarbi I (2002) À propos de la corpulence des bovins en France Durant les pèriodes historiques. Gallia 59:273-306

Frosdick R (2014) Status and new beginnings: archaeozoological research into the early medieval rural settlements of Northwest Switzerland. PhD dissertation, Universität Basel

García-Collado MI (2020) Social archaeology of food in early medieval rural Iberia (5th-9th c. AD). PhD dissertation, University of the Basque Country

Grant A (2004) Domestic animals and their uses. In: Todd M (ed.), A companion to Roman Britain. Malden, Oxford, Victoria: Blackwell, pp. 371-392

Grau-Sologestoa I (2015a) Livestock management in Spain from Roman to post-medieval times: a biometrical analysis of cattle, sheep/goat and pig. J Archaeol Sci 54:123-134

Grau-Sologestoa I (2015b) The zooarchaeology of medieval Alava in its Iberian context. BAR, Oxford

Grau-Sologestoa I, Albarella U (2019) The 'long' sixteenth century: a key period of animal husbandry change in England. Archaeol Anthropol Sci 11:2781-2803. https://doi.org/10.1007/ s12520-018-0723-6

Grau-Sologestoa I, Ginella F, Marti-Grädel E, Stopp B, Deschler-Erb S (2021) A biometrical database of cattle, sheep and pig from Roman and medieval Switzerland and adjacent areas of France. Zenodo. https://doi.org/10.5281/zenodo.4707131

Groot M (2017) Developments in animal husbandry and food supply in Roman Germania Inferior. Eur J Archaeol 20:451-471. https://doi.org/10.1017/eaa.2016.31

Groot M, Deschler-Erb S (2015) Market strategies in the Roman provinces: different animal husbandry systems explored by a comparative regional approach. J Archaeol Sci Rep 4:447-460

Groot M, Deschler-Erb S (2016) Carnem et circenses - consumption of animals and their products in Roman urban and military sites in two regions in the northwestern provinces. Environ Archaeol 22(1):96-112

Grunenfelder HP (2006) Prespa cattle. Identification and possible conservation measures. Monitoring Institute for rare breeds and seeds in Europe and SAVE foundation. http://www.savefoundation.net/images/projekte/mittelmeer/prespa-en.pdf. Accessed 30 Aug 2021.

Grunenfelder HP (2014) Prespa dwarf cattle in Albania: conservation through use and local responsibility. SAVE foundation. http:// www.save-foundation.net/images/projekte/balkan/Prespa_Cattt le_AL_Final_Report_2014.pdf. Accessed 30 Aug 2021.

Hamerow H, Bogaard A, Charles M, Forster E, Holmes M, McKerracher M, Neil S, Bronk Ramsey C, Stroud E, Thomas R (2020) An integrated bioarchaeological approach to the Medieval 'agricultural revolution': a case study from Stafford, England, c. ad 800-1200. Eur J Archaeol 23(4):585-609. https://doi.org/ 10.1017/eaa.2020.6

Hamerow H, Bogaard A, Charles M, Ramsey C, Thomas R, Forster E, Holmes M, McKerracher M, Neil S, Stroud E (2019) Feeding Anglo-Saxon England: the bioarchaeology of an agricultural revolution. Antiquity 93(368):E12. https://doi.org/10. 15184/aqy.2019.27
Hammon A (2011) Understanding the Romano-British-Early Medieval transition: a zooarchaeological perspective from Wroxeter (Viroconium Cornoviorum). Britannia 42:275-305

Hammond J (1960) Farm animals: their breeding, growth and inheritance. Edward Arnold, London

Heather P (2005) The fall of the Roman Empire: a new history of Rome and the Barbarians. Oxford University Press, Oxford

Henning J (2009) Revolution or relapse? Technology, agriculture and early medieval archaeology in Germanic Central Europe. In: Ausenda G, Delogu P, Wickham C (eds) The Langobards before the Frankish conquest, an ethnographic perspective. Boydell Press, Woodbridge, pp 149-173

Henning J (2012) Did the "agricultural revolution" go east with Carolingian conquest? Some reflections on early medieval rural economics of the Baiuvarii and Thuringi. In: Ausenda G, Hines J, Steuer H (eds) Baiuvarii and Thuringi: an ethnographic perspective, Studies in Historical Archaeoethnology. Center for Interdisciplinary Research on Social Stress, San Marino

Hodges R (2012) Dark Age economics. A new audit. Bloomsbury, London

Hodges R, Bowden W (1998) The sixth century: production, distribution, and demand. Brill, Leiden

Holmes M (2014) Does size matter? Changes in the size of the animals throughout the English Saxon period. J Archaeol Sci 43:77-90

Horber E (2020) http://www.unige.ch/ses/sococ/cl//edoc/spssresources. html (Accessed on 16.10.2020)

Joerin UE, Stocker TF, Schlüchter C (2006) Multicentury glacier fluctuations in the Swiss Alps during the Holocene. Holocene XVI: 697-704. https://doi.org/10.1191/0959683606hl964rp

Kron G (2002) Archaeozoological evidence for the productivity of Roman livestock farming. Münstersche Beiträge Zur Antiken Handelsgeschichte 21:53-73

Lauwerier RCGM (1988) Animals in Roman times in the Dutch Eastern River Area. ROB, Amersfoort

Lepetz S (1995) L'amélioration des races a l'époque gallo-romaine: l'exemple du boeuf. Home Et Animal Dans L'antiquité Romaine, Actes Du Coloque De Nantes, Université De Tours 1991:67-78

Lepetz S (1996) L'amélioration des espèces animals domestiques à la période romaine en France du Nord. In: Meeks D, Garcia D (eds.) Techniques et économie antiques et médiévales: le temps de l'innovation, Errance, pp. 157-165

Lewit T (2009) Pigs, presses and pastoralism: farming in the fifth to sixth centuries AD. Early Medieval Europe 17(1):77-91

Lodwick L, Campbell G, Crosby V, Müldner G. (2020) Isotopic evidence for changes in cereal production strategies in Iron Age and Roman Britain, Environmental Archaeology: 1-16

Mackinnon M (2004) Production and consumption of animals in Roman Italy: integrating the zooarchaeological and textual evidence. J Roman Archaeol (Suppl. m. 54)

MacKinnon M (2001) High on the hog: linking zooarchaeological, literary, and artistic data for pig breeds in Roman Italy. Am J Archaeol 105:649-673

Mariezkurrena K (2004) Talla del bovino en el País Vasco durante la Edad del Hierro y las épocas romana y medieval. Munibe 56:79-86

Marti R (2000) Zwischen Römerzeit und Mittelalter. Forschungen zur frühmittelalterlichen Siedlungsgeschichte der Nordwestschweiz (4.-10. Jahrhundert). Archäologie und Museum 41, Liestal

Marti R (2008) Spätantike und frühmittelalterliche Höhensiedlungen im Schweizer Jura. In: Bierbrauer V, Steuer H (eds.), Höhensiedlungen zwischen Antike und Mittelalter von den Ardennen bis zur Adria. Reallexikon der Germanischen Altertumskunde Ergänzungsband 58. Berlin/New York, pp. 341-380 
Marti R (2009) Between ager and silva - phases of the colonization and the use of land in Northern Switzerland from the 2nd/3rd to the 8th/9th century. In: Klápště J, Sommer P (eds.) Medieval rural settlement in marginal landscapes. Ruralia 7. Turnhout, pp. 291-307

Marti-Grädel E (2012) Archäozoologische Untersuchungen der Tierknochen aus der Burgstelle Altenberg, Kt. Basel-Landschaft (11. Jahrhundert): im Kontext früh- bis hochmittelalterlicher Siedlung der Region (5.-12. Jahrhundert): Wirtschafts- und Umweltgeschichte des Früh- und Hochmittelalters in der Nordwestschweiz. $\mathrm{PhD}$ dissertation, Universität Basel

Marti-Grädel E (2013) Tier- und Pflanzenreste. In: Marti R, Meyer W, Obrecht J (dir.) Der Altenberg bei Füllinsdorf. Eine Adelsburg des 11. Jahrhunderts. Schriften der Archäologie Baselland 50 (Basel 2013), pp. 316-361

Marti-Grädel E, Hüster-Plogmann H (2014) Genutzte Tiere. In: Niffeler U (dir.) (2014) Archäologie der Zeit von 800 bis 1350 L'archéologie de la période entre 800 à 1350 - L'archeologia del periodo tra l'800 ed il 1350, SPM VII. Basel: Verlag Archäologie Schweiz, pp. 72-77

McCormick F, Kerr TR, McClatchie M, O'Sullivan A (2014) Early Medieval agriculture, livestock and cereal production in Ireland, AD 400-1100. BAR, Oxford

McCormick M, Büntgen U, Cane MA, Cook ER, Harper K, Huybers P, Litt T, Manning SW, Mayewski PA, More AFM, Nicolussi K, Tegel W (2012) Climate change during and after the Roman Empire: reconstructing the past from scientific and historical evidence. Journal of Interdisciplinary History XII $\mathrm{I}(2): 169-220$

Meadow R (1999) The use of size index scaling techniques for research in archaeozoological collections from the Middle East. In: Manhart H, Peters J, Schibler J (eds) Historia animalium ex ossibus: Beitrage zur Paläoanatomie, Archäologie, Ägyptologie, Ethnologie und Geschichte der Tiermedizin. Verlagmarie Leidorf $\mathrm{GmbH}$, Rahden/Westf, Festschrift für Angela von den Driesch, pp 285-300

Méniel P (1996) Importation de grands animaux romains et amélioration du cheptel à la fin de l'Âge du Fer en Gaule Belgique. Revue Archéologique De Picardie 3:113-122

Minniti C, Valenzuela-Lamas S, Evans J, Albarella U (2014) Widening the market. Strontium isotope analysis on cattle teeth from Owslebury (Hampshire, UK) highlights changes in livestock supply between the Iron Age and the Roman period. J Archaeol Sci 42:305-314. https://doi.org/10.1016/j.jas.2013.10.008

Moreland J (2011) Land and power from Roman Britain to AngloSaxon England? Hist Mater 19(1):175-193

Murphy P, Albarella U, Germany M, Locker A (2000) Production, imports and status: biological remains from a Late Roman farm at Great Holts Farm, Boreham, Essex, UK. Environ Archaeol 5:35-48

Niffeler (dir.) U (2014) Archäologie der Zeit von 800 bis 1350 L'archéologie de la période entre 800 à 1350 - L'archeologia del periodo tra l'800 ed il 1350, SPM VII. Verlag Archäologie Schweiz, Basel

O'Connor T (2010a) Livestock and deadstock in early medieval Europe from the North Sea to the Baltic. Environ Archaeol 15:1-15

O'Connor T (2010b) Animal husbandry. In: Hamerow H, Hinton DA, Crawford S (eds) The Oxford Handbook of Anglo-Saxon Archaeology. Oxford University Press, Oxford, pp 361-376

O'Connor T (2014) Livestock and animal husbandry in Early Medieval England. Quatern Int 346:109-118

Palet JM (1999-2000) Dinámica territorial de l'antiguitat a l'edatmitjana a Catalunya: arqueomorfología i estudi de casos. In: Bolos J, Busqueta JJ (eds.) Territori i societat a l'EdatMitjana, Història, arqueología, documentació, v. III, pp. 75-110. Lleida
Payne S, Bull G (1988) Components of variation in measurements of pig bones and teeth, and the use of measurements to distinguish wild from domestic pig remains. Archaeozoologia II/1(2):27-66

Peters J (1998) Römische Tierhaltung und Tierzucht. Eine Synthese aus archäozoologischer Untersuchung und schriftlichbildlicher Überlieferung. Passauer Universitätsschriften zur Archäologie, Band 5. Verlag Marie Leidorf GmbH, Rahden

Pigière F (2017) The evolution of cattle husbandry practices in the Roman period in Gallia Belgica and Western Germania Inferior. Eur J Archaeol 20:472-493

Pigière F, Akeret Ö, Kühn M (eds.) (2019). Special issue "Food production and Land Use". Quaternary International 499(Part A): 1-128. https://doi.org/10.1017/eaa.2017.1

Pryce JE, Haile-Mariam M, Goddard ME, Hayes BJ (2014) Identification of genomic regions associated with inbreeding depression in Holstein and Jersey dairy cattle. Genet Sel Evol 46(1):71. https:// doi.org/10.1186/s12711-014-0071-7

Putelat O (2015) Les relations homme-animal dans le monde des vivants et des morts. Étude archéozoologique des établissements et des regroupements funéraires ruraux de l'Arc Jurassien et de la Plaine d'Alsace de la fin de l'Antiquité Tardive au Premier Moyen Âge. PhD Dissertation, Université Paris 1 Panthéon-Sorbonne

Quirós Castillo JA (ed) (2013) El poblamiento rural de época visigoda en Hispania. Arqueología del campesinado en el interior peninsular, Documentos de Arqueología Medieval 6. UPV-EHU, Bilbao

Quirós Castillo JA (ed.) (2014) Special issue "Agrarian Archaeology in Early Medieval Europe". Quat Int 346: 1-162

Rehazek A (2010) Die archäozoologische Analyse von mittelalterlichen und neuzeitlichen Tierknochen aus der Stadt und dem Kanton Bern. Ein Beitrag zur Wirtschafts- und Alltagsgeschichte vom 6./8. bis ins 19./20. Jahrhundert. PhD dissertation, Universität Basel

Rizetto M, Crabtree PJ, Albarella U (2017) Livestock changes at the beginning and end of the Roman period in Britain: issues of acculturation, adaptation and 'improvement. Eur J Archaeol 20(3):535-556

Rosenthal R (1991) Meta-analysis procedures for social research, 2nd edn. Sage, Newbury Park

Salvadori F (2015) Uomini e animali nel Medioevo. Ricerche Archeozoologiche in Italia. Edizione Accademiche Italiane, Saarbrücken

Schibler J, Furger AR (1988) Die Tierknochenfunde aus Augusta Raurica (Grabungen 1955-1974). Forschungen in Augst 9. Augst: Römermuseum Augst

Schlumbaum A, Turgay M, Schibler J (2006) Near East mtDNA haplotype variants in Roman cattle from Augusta Raurica, Switzerland, and in the Swiss Evolene Breed. Anim Genet 37:373-375

Schwarz P-A (2011) Das Castrum Rauracense und sein Umland zwischen dem späten 3. und dem frühen 7. Jahrhundert. In: Konrad M, Witschel C (eds) Römische Legionslager in den Rhein- und Donauprovinzen - Nuclei spätantik-frühmittelalterlichen Lebens? Verlag der Bayerischen Akademie der Wissenschaften, München, pp 307-349

Steiner H (2014) Historisch-ereignisgeschichtlicher Rahmen. In: Niffeler U (ed) Archäologie der Zeit von 800 bis 1350, SPM VII. Verlag Archäologie Schweiz, Basel, pp 33-61

Stephan E (2008) Haustiere in alamannischer Zeit. In: Ade D, Rüth B, Zekorn A (eds) Alamannen zwischen Schwarzwald, Neckar und Donau. Begleitbuchzur-Wanderausstellung, Stuttgart, pp 86-87

Sutherland TM, Lush JL (1962) Effects of inbreeding on size and type in Holstein-Friesian cattle. J Dairy Sci 45:390-395

Tecce S, Albarella U (2020) Did early farmers keep pigs? A morphometric analysis from Italy. In: Sørensen L, Rowley-Conwy P (eds) Gron KJ. Oxbow Books, Farmers at the Frontier. A PanEuropean Perspective on Neolithisation. Oxford and Philadelphia, pp 101-124

Teichert M (1984) Size variation in cattle from Germania Romana and Germania Libera. In: Grigson C, Clutton-Brock J (eds) Animals 
and Archaeology 4. Husbandry in Europe. BAR International Series 227. BAR, Oxford

Thomas R (2005) Zooarchaeology, improvement and the British agricultural revolution. Int J Hist Archaeol 2:71-87

Trentacoste A, Nieto-Espinet A, Guimarães S, Wilkens B, Petrucci G, Valenzuela-Lamas S (2021) New trajectories or accelerating change? Zooarchaeological evidence for Roman transformation of animal husbandry in Northern Italy. Archaeological and Anthropological Sciences 13 (25). https://doi.org/10.1007/ s12520-020-01251-7

Trixl S, Steidl B, Peters J (2017) Archaeology and zooarchaeology of the Late Iron Age-Roman transition in the province of Raetia (100 BC-100 AD). Eur J Archaeol 20:431-450. https://doi.org/ 10.1017/eaa.2016.25

Valenzuela A, Alcover JA, Cau MA (2017) The impact of Roman conquest on the pattern of livestock exploitation on the Balearic Islands. Archaeofauna 26:127-142

Valenzuela-Lamas S, Detry C (2017) Romanización y Arqueozoología en el limes del Imperio. El caso de Lusitania entre la Edad del Hierro y el Bajo Imperio (s. VIII aC-V dC). Archaeofauna 26:39-51

von den Driesch A (1992) L'elevage des animaux domestiques dans les cultures européenes pré- et protohistoriques. Rev Med Vétérinaire 143:113-137

Ward-Perkins B (2006) The fall of Rome and the end of civilization. Oxford University Press, Oxford
Wick L (2015) Das Hinterland von Augusta Raurica: Paläo-ökologische Untersuchungen zur Vegetation und Landnutzung von der Eisenzeit bis zum Mittelalter. Jahresberichte Aus Augst Und Kaiseraugst 36:209-215

Wickham C (2005) Framing the Middle Ages. Oxford University Press, Oxford

Wickham C (2009) The inheritance of Rome: a history of Europe from 400 to 1000 . Allen Lane, London

Widdowson EM, Lister D (1991) Nutritional control of growth. In: Pearson AM, Dutson TR (eds.) Growth regulation in farm animals. Advances in Meat Research 7. London: Elsevier Applied Science, pp. 67-101

Windler R, Fuchs M (eds.) (2002) De l'Antiquité tardive au Haut Moyen-Âge (300-800): Kontinuität und Neubeginn, Antiqua 35. Basel: Schweizerische Gesellschaft für Ur- und Frühgeschichte

Windler R, Marti R, Niffeler U, Steiner L (eds.) (2005) Frühmittelalter - Haut Moyen-Âge - Alto Medioevo, SPM VI. Basel: Schweizerische Gesellschaft für Ur- und Frühgeschichte

Wolfhagen J (2020) Re-examining the use of the LSI technique in zooarchaeology. J Archaeol Sci 123:105254

Yvinec J-H (1991) Bilan et problématique en archéozoologie du Haut Moyen Age. Archéologie de la Vallée de L'Oise

Publisher's Note Springer Nature remains neutral with regard to jurisdictional claims in published maps and institutional affiliations. 